\title{
REVISIÓN DE LOS GRUPOS DE ESPECIES DEL GÉNERO BLECHNUM (BLECHNACEAE-PTERIDOPHYTA): EL GRUPO $B$. PENNA-MARINA
}

\author{
Cristina H. ROLLERI y Carmen PRADA
}

\begin{abstract}
RESUMEN. Revisión de los grupos de especies del género Blechnum (Blechnaceae-Pteridophyta): el grupo B. penna-marina. Blechnum asperum, B. penna-marina, B. spicant y B. stoloniferum (grupo $B$. penna-marina) se estudian aquí conjuntamente con' $B$. blechnoides, $B$. corralense, $B$. fernandezianum, B. lehmannii, B. microphyllum, B. mochaenum subsp. mochaenum, B. mochaenum subsp. achalense y $B$. mochaenum subsp. squamipes. Los esporófitos de estos taxones son pequeños a medianos, con rizomas postrados a erectos y frondas dimórficas. Los caracteres analizados fueron: tipo de rizoma, indumento de ejes y lámina, arquitectura de las frondas, todas con segmentos adnatos y estípites con tres haces vasculares, venación, morfología interna de los segmentos, tales como estructura marginal, modelos epidérmicos de la lámina, estomas, hidatodos, secciones transversales de los estípites, modelos epidérmicos de los indusios y esporas. Esos caracteres resultan 'diagnósticos para distinguir los taxones. Se encontraron protuberancias intercelulares pécticas (PIP) en forma de verrugas y filamentos cortos en el mesofilo y tejidos parenquimáticos del estípite y raquis de algunas especies. En el parénquima de los estípites se acumula a menudo almidón de granos simples, elipsoidales. Las esporas son monoletes, aclorofílicas, con esporodermo formado por un exosporio psilado y un perisporio cuya ornamentación varía en los niveles específico e infraspecífico. Tres especímenes de B. penna-marina y tres de B. mochaenum subsps. mochaenum presentaron esporas, células epidérmicas y estomas más grandes que el resto, lo que sugiere diferencias de ploidía, aunque esos ejemplares no muestran variaciones morfológicas externas o internas. Se ha cambiado el estatus de las variedades de $B$. mochaenum como sigue: $B$. mochaenum var. fernandezianum es reconocido con el rango de especie, mientras que $B$. mochaenum var. squamipes y $B$. mochaenum var. achalense son elevadas al rango de subespecie. Blechnum microphyllum se trata aquí como una especie bien caracterizada y no una subespecie de B. penna-marina. Las plantas de B. penna-marina de Argentina, Brasil y Chile varían algo en el tamaño, pero los rasgos de la morfología interna son muy constantes y no se han reconocido subespecies en el área. Se presenta una descripción completa de los taxones, se actualizan aspectos nomenclaturales, sinonimia, tipos, distribución geográfica, ecología, se da una clave para su determinación y se discute la importancia de los caracteres analizados para redefinir el grupo.
\end{abstract}

Palabras clave. Blechnum, Blechnaceae, grupos de especies, estatus nuevos, caracteres diagnósticos, morfología, esporófito, esporas.

ABSTRACT. Revision of the groups of species in genus Blechnum (Blechnaceae-Pteridophyta): the $B$. penna-marina group. Blechnum asperum, B. penna-marina, B. spicant and B. stoloniferum ( $B$. penna-marina group) are studied here together with $B$. blechnoides, $B$. corralense, $B$. fernandezianum, B. lehmannii, B. microphyllum, B. mochaenum subsp. mochaenum, B. mochaenum subsp. squamipes, and $B$. mochaenum subsp. achalense. The sporophytes of these taxa are small to medium plants with postrate to erect rhizomes, and dimorphic fronds. Characters selected to study were type of rhizome, 
indument of the axes and laminae, architecture of fronds, which always bear adnate segments and stipes with three vascular strands, venation, internal morphology of segments, such as margins, epidermal patterns of laminae, stomata, hydathodes, transversal section of stipes, epidermal patterns of indusia, and spores. These traits bring diagnostic characters to distinguish the taxa. Intercellular pectic protuberances (IPP), mostly warts and short filaments, were detected in the mesophyll cells, and within the parenchymatose tissues of the stipes and rachis in some taxa. Ellipsoidal starch grains often accumulate within the parechymatose tissues of stipes. The spores are monolete, ellipsoidal, non-chlorophyllous, with a sporoderm consisting of a psilate exospore, and a perispore which ornamentation varies in the specific and infraspecific levels. Three specimens of $B$. penna-marina and three specimens of $B$. mochaenum subsp. mochaenum showed spores, epidermal cells and stomata larger than average, thus suggesting a difference of ploidy, although the plants do not show significant differences in their external morphology. The status of the varieties of $B$. mochaenum are changed as follow: B. mochaenum var. fernandezianum is recognized as a different species, B. fernandezianum, while B. mochaenum var. squamipes and B. mochaneum var. achalense are both considered as subspecies. Blechnum microphyllum is treated as a well delimitated species, instead of a subspecies of B. penna-marina. Plants of $B$. penna-marina from Argentina, Brasil and Chile may vary in size and external coloration of pinnae, but internal morphology remains constant, and no subspecies were recognized in the area. A new, complete description is presented for each taxon, along with their taxonomy, distribution, ecology and a key to identify them. The importance of the studied characters to define the group is discussed.

Key words. Blechnum, Blechnaceae, groups of species, diagnostic characters, new status, morphology, sporophyte, spores.

\section{INTRODUCCIÓN}

Tryon \& Tryon (1982) subdividieron el género Blechnum L. en siete grupos informales, cada uno con el nombre de una especie representativa: grupo $B$. buchtienii Rosenst., grupo B. fragile (Liebm.) C. V. Morton \& Lellinger, grupo B. lineatum (Sw.) C. Chr., grupo B. loxense (Kunth) Hook. ex Salomon, grupo $B$. occidentale L., grupo $B$. penna-marina (Poir.) Kuhn y grupo $B$. serrulatum Rich.. Las especies fueron agrupadas sobre la base de los caracteres de sus ejes y frondas, cuyo dimorfismo o monomorfismo se consideró un rasgo de grupo y por lo tanto, sin importancia sistemática en el nivel genérico, algo que ya había sugerido Copeland (1947). Oliveira Dittrich (2005) tomó los grupos informales como base para un estudio taxonómico de las especies de Blechnum del S-SE de Brasil y propuso dividir el grupo $B$. lineatum en dos: grupo B. cordatum (Desv.) Hieron. y grupo $B$. divergens (Kunze) Mett., sobre la base del grado de unión de las pinnas con el raquis, la presencia o ausencia de escamas en los ejes, la presencia o ausencia de aeróforos o bulbillos, los números cromosómicos básicos diferentes y la ecología de las especies. Además, cambió el nombre del grupo $B$. fragile por el de $B$. binervatum (Poir.) C. V. Morton y el de $B$. buchtienii por el de B. tabulare (Thunb.) Kuhn, optando por la utilización de los nombres de las especies más antiguas de cada uno, algo innecesario dado que los grupos carecen de jerarquía taxonómica.

Hay abundante bibliografía sobre el género, incluyendo floras, catálogos y revisiones parciales como los trabajos de Schelpe (1952), de la Sota $(1973 ; 1977)$, Taylor (1970), Scoggan (1978), Stolze (1981), Lellinger (1985, 2003), Marticorena \& Quezada (1985), Burrows (1990), Tryon \& Stolze (1993), Rodríguez Ríos (1995), Moran (1995), Chambers \& Farrant (1996 a-b), Kazmirczak (1999), Oliveira Dittrich (2005) y Rolleri \& Prada (2006), así como 
análisis sobre morfología externa o interna de algunas especies, como los trabajos de de la Sota (1970 a-b, 1972 a-b), Rolleri (1976, 1984) y Durán (1997). Thurston (1969) y van Cotthem $(1970,1973)$ analizaron los estomas de pteridófitos en general y describieron los de Blechnaceae como polocíticos. Prabhakar (2003), en una revisión de tipos estomáticos, sinonimizó el término polocítico con el de diacítico y el de axilocítico con el de anomocítico, entre otros, sugiriendo utilizar los nombres originales por razones de prioridad. Gardiner (1885), Mangin (1893) y Luerssen (1875) dieron a conocer la presencia de verrugas pécticas en estípites de tres especies de Blechnum: B. brasiliense Desv., B. cartilagineum Sw. y B. procerum (Forst f. ) Sw. Tales verrugas, junto con los filamentos y las conexiones pécticas fueron colectivamente llamadas protuberancias intercelulares pécticas por Potgieter \& van Wyk (1992), un nombre adoptado después por Rolleri et al. (1999) y Prada \& Rolleri (2005), que se usa también aquí. Los únicos estudios citológicos que involucran especies del grupo B. penna-marina son los de Manton et al. (1986), Horjales et al. (1990) y Jara-Seguel et al. (2006).

Con el fin de poner a prueba los grupos informales y de encontrar caracteres diagnósticos que puedan aplicarse al género, se ha comenzado con el análisis del grupo B. penna-marina. Tryon \& Tryon (1982) incluyeron originalmente en este grupo a $B$. asperum (Klotzsch) J.W. Sturm., B. andinum (Baker) C. Chr., B. penna-marina, B. spicant L. y B. stoloniferum (Mett. ex E. Fourn) C. Chr. En este estudio se han incoporado $B$. blechnoides (Bory) Keyserl., B. corralense Espinosa, B. fernandezianum (Looser) Prada \& Rolleri, B. lehmannii Hieron., $B$. microphyllum (Goldm.) C.V. Morton, $B$. mochaenum G. Kunkel subsp. mochaenum, B. mochaenum subsp. squamipes (Hieron.) Prada \& Rolleri, ya incluida en el grupo, con rango de variedad, por Oliveira Dittrich (2005) y B. mochaenum subsp. achalense (Hieron.) Prada \& Rolleri.

Todos los taxones estudiados tienen en común la arquitectura foliar, las frondas dimórficas, las láminas estériles con segmentos adnatos, las láminas fértiles con segmentos reducidos a la porción esporógena, los estípites con 3 haces vasculares y la reproducción vegetativa por medio de estolones. Con excepción de $B$. lehmannii, que tiene amplia distribución en Centroamérica y Sudamérica, $B$. stoloniferum, un elemento mesoamericano, $B$. blechnoides, que vive en Chile y Nueva Zelanda, entre $\operatorname{los} 40^{\circ}$ y los $50^{\circ}$ de latitud S (Chambers \& Farrant, 1996 b) y B. spicant, una especie holártica, los restantes taxones estudiados viven en el cono sur y el S-SE de Brasil.

La bibliografía previa sobre la utilización de caracteres morfológicos en especies del grupo no es muy abundante: Rodríguez Ríos (1973), en un trabajo sobre gametófitos que incluye los de $B$. pennamarina y $B$. microphyllum, analizó los caracteres epidérmicos de las frondas juveniles en esas y otras especies de Blechnum, Sperry (1983) estudió la morfología y fisiología de los hidatodos deB. lehmannii y Durán (1997) trató comparativamente varios de los taxones tratados aquí en una monografía sobre el género Blechnum en la Argentina.

En este trabajo se han estudiado los siguientes rasgos del esporófito: los tipos de rizoma y la presencia de estolones como medio de reproducción vegetativa, el indumento de los ejes, la división de la lámina, el contorno, textura, tamaño, margen, indumento superficial, venación, modelo epidérmico, estomas (densidad y dimensiones) e hidatodos de los segmentos estériles, la presencia y tipos de protuberancias intercelulares pécticas en 
estípites y mesofilo de frondas estériles y fértiles, la morfología interna de los estípites, incluyendo el tipo de epidermis, el grado de desarrrollo del tejido fibroso y parenquimático, la presencia de parénquima amiláceo y número de haces vasculares presentes, los tipos de márgenes y modelos epidérmicos de los indusios y las esporas. Se presenta una descripción actualizada de los taxones, una clave para su determinación, comentarios sobre relaciones interespecíficas, afinidades, ecología y distribución geográfica. Se hacen consideraciones sobre la utilidad de los grupos informales y la importancia de los caracteres diagnósticos en el grupo estudiado.

\section{MATERIALES Y MÉTODOS}

Los estudios del esporófito se efectuaron en material de los herbarios CONC, LIL, LP, MACB y US (Holmgren et al. 1990).

El material se restauró con una mezcla de butil cellosolve y agua 1:4. Las pinnas se aclararon con hidróxido de sodio al $6 \%$ y se colorearon con azul de toluidina (en adelante TBO) $1 \%$, que sirve adicionalmente para detectar la presencia y tipos de protuberancias intercelulares pécticas (PIP) en cortes transversales de mesofilo y ejes y la naturaleza del tejido de sostén hipodérmico de los estípites. Las PIP reaccionan dando color rosa intenso por su naturaleza pectinada. Las células hipodérmicas de sostén están lignificadas y dan reacción de color verde intenso con el TBO.

La venación y los modelos epidérmicos se analizaron en todas las pinnas pero se ilustran los correspondientes a las pinnas medias. Las dimensiones y densidad de los estomas se tomaron en todos los ejemplares estudiados; las dimensiones se expresan en largo $\mathrm{x}$ ancho, en $\mu \mathrm{m}$ y la densidad en número de estomas por $\mathrm{mm}^{2}$.

Las muestras de esporas se tomaron de especímenes de todas las localidades de cada taxón y se seleccionaron de plantas de diferentes tamaños. Se midieron todos los ejemplares con microscopio óptico (diámetro mayor x diámetro menor, en $\mu \mathrm{m}$ ). Para estudios con microscopía electrónica de barrido, la esporas se montaron sin tratamiento, se cubrieron con oro bajo vacío, en un metalizador Jeol JSM 1100. Las fotografías se tomaron con un microcopio electrónico Jeol JFC T100.

Toda la terminología relacionada con el esporófito está en Lellinger (2002), la referente a la epidermis es la que han utilizado las autoras en trabajos pteridológicos previos, como Rolleri (2004) y Prada \& Rolleri (2005), la relacionada con los estomas se ha tomado de Prabhakar (2003) y la referente a las esporas, con algunas variantes, de Lellinger \& Taylor (1997) y Lellinger (2002). Los caracteres del esporófito se resumieron en la tabla 1.

\section{RESULTADOS Y DISCUSIÓN}

\section{Morfología del esporófito}

Los rizomas son erectos a postrados, cortamente reptantes o algo extendidos, subterráneos a emergentes y están cubiertos por escamas. Producen estolones delgados y abundantes en todos los taxones (esto es variable en B. lehmannii), desnudos o portadores de pequeños apéndices foliares aflébicos, reducidos a láminas semicirculares distantes. Son erectos o suberectos en $B$. asperum, B. blechnoides, B. corralense, $B$. fernandezianum, B. mochaenum subsp. mochaenum, B. mochaenum subsp. achalense, B. mochaenum subsp. squamipes, $B$. spicant y $B$. stoloniferum; gruesos o delgados, cortamente rastreros y luego erectos en en B. lehmannii, B. microphyllum y $B$. penna-marina. Llevan abundantes raíces muy delgadas, protostélicas (diarcas).

Están formados por los siguientes 


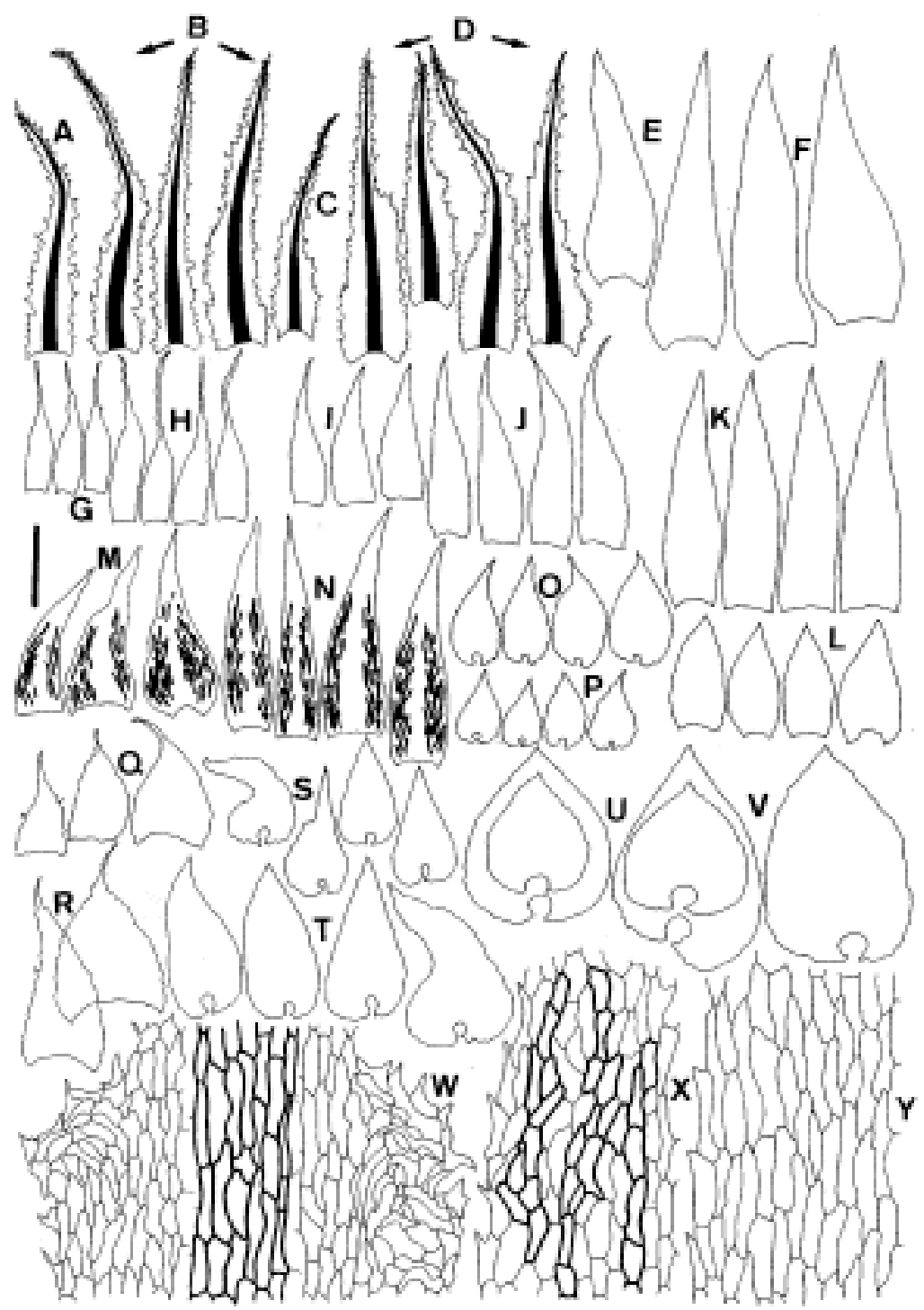

Figura 1. Escamas del rizoma y estípite en especies de Blechnum. A-D: B. spicant A-B: Escamas del estípite. C-D: Escamas rizomáticas. E-F: B. blechnoides. E: Escama basal del estípite. F: Escamas rizomáticas. G-H: B. fernandezianum. G: Escamas basales del estípite. H: Escamas rizomáticas (en G-H, no ilustradas las áreas esclerosadas). I-J: B. mochaenum subsp. squamipes. I: Escamas basales del estípite. J: Escamas rizomáticas. K-L: B. stoloniferum. K: Escamas rizomáticas. L: Escamas basales del estípite. M-N: B. mochaenum subsp. mochaenum. M: Escamas basales del estípite. N: Escamas rizomáticas. O-P: $B$. corralense. O: Escamas rizomáticas. P: Escamas basales del estípite. Q-R: $B$. mochaenum subsp. achalense. Q: Escamas basales del estípite. R: Escamas rizomáticas. S-T: $B$. pennamarina. S: Escamas basales del estípite. T: Escamas rizomáticas. U-V: B. microphyllum. U: Exteriores, escamas rizomáticas, interiores, escamas basales del estípite. V: Escama rizomática. W: Detalle en AD. X: Detalle en M-N. Y: Detalle en escama rizomática de B. stoloniferum (generalizado en escamas concolores). Barra: $1 \mathrm{~mm}$ en A-D, H-L, O-T; 2 mm en E-F, M-N; 0,2 mm en W-Y. 
tejidos: una epidermis papilosa, cuyas paredes celulares externas están engrosadas y cutinizadas, una zona hipodérmica de sostén formada por células engrosadas y lignificadas y un área central parenquimática cuyas células se disponen con espacios intercelulares pequeños y pueden contener almidón. La estela es una dictiostela con 57 meristelas, generalmente 2-3 más pequeñas, rodeadas por una endodermis con engrosamientos en bandas de Caspary o en U y por 2-3 capas de células engrosadas no esclerosadas. Los estolones son externamente estriados y tienen los mismos tipos de tejidos que el rizoma. El parénquima central puede ser amiláceo (B. mochaenum, $B$. corralense y B. lehmannii) o carecer de almidón (B. microphyllum y'B. pennamarina) y las estelas tienen menos meristelas que las de los rizomas (1-2 en $B$. corralense y 4-5 en los taxones restantes).

Las escamas del rizoma y los estípites (fig. 1) son basifijas y casi conformes aunque difieren en el tamaño. Las escamas del rizoma son discolores o concolores y siempre algo más grandes que las de los estípites. Son discolores en $B$. fernandezianum, $B$. lehmannii, $B$. mochaenum subsp. mochaenum y B. spicant. Las escamas de $B$. mochaenum subsp. mochaenum (fig. $1 \mathrm{M}-\mathrm{N}$ ) y B. lehmannii tienen áreas irregulares formadas por células engrosadas y esclerificadas y oscuras, distribuidas al azar en B. mochaenum subsp. mochaenum (fig. 1 $\mathrm{M}-\mathrm{N}$ ), a veces también en los márgenes en $B$. fernandezianum (fig. $1 \mathrm{G}-\mathrm{H}$ ) y $B$. lehmannii, en ésta con dientes marginales espaciados, curvados basiscópicamente, o en forma de un área esclerificada central angosta que va desde la base hasta el ápice de la escama, como si fuera una vena, en $B$. spicant (fig. 1 A-D). El ápice de estas escamas suele ser oscuro, glandular, a veces esclerosado y retorcido. Son concolores, de color castaño claro a castaño rojizo, en los taxones restantes, aunque pueden ser oscuras y endurecidas, por esclerosis completa, en plantas maduras de B. blechnoides. Los estípites presentan escamas basales rojizas caducas en casi todos los taxones, con excepción de B. blechnoides que tiene escamas persistentes que pueden estar endurecidas en los estípites de las plantas más grandes, al igual que las del rizoma. Los estípites de $B$. corralense, $B$. fernandezianum, B. mochaenum subsp. achalense y $B$. spicant tienen, además de escamas basales, pelos similares a los que se encuentran en la superficie de la lámina.

Las escamas tienen contornos linear lanceolados en rizomas y estípites de $B$. spicant (fig. 1 A-D), lanceolados en $B$. blechnoides (fig. 1 E-F), B. fernandezianum (fig. $1 \mathrm{G}-\mathrm{H}$ ) , B. lehmannii, B. mochaenum subsp. squamipes (fig. 1 I-J) y en rizomas de $B$. stoloniferum (fig. $1 \mathrm{~K}$ ); deltoides a lanceolado-deltoides, con ápices largamente atenuados en B. mochaenum subsp. mochaenum (fig. $1 \mathrm{M}-\mathrm{N}$ ), B. mochaenum subsp. achalense (fig. 1 Q-R) y B. pennamarina (fig. $1 \mathrm{~S}-\mathrm{T}$ ), con bases rectas amplias en las dos subespecies y con bases redondeadas a casi auriculadas en $B$. pennamarina. Finalmente, los contornos son ovados, con ápices cortamente agudos y retorcidos en $B$. corralense (fig. 1 O-P) y en las escamas del estípite de $B$. stoloniferum (fig. 1 L) y anchamente ovados a casi orbiculares, con base cordada y ápice obtuso o redondeado en $B$. microphyllum (fig. $1 \mathrm{U}$ V). Los márgenes son enteros en las escamas de $B$. blechnoides, marcadamente denticulados en las de B. lehmannii, con dentículos 1-3-celulares, distantes, engrosados y retrorsos o con dientes marginales pluricelulares que a la vez presentan dentículos menores, curvos y retrorsos que llegan hasta los ápices, en las de $B$. spicant (fig. $2 \mathrm{~W}$ ), o bien son subenteros o con tienen dentículos 1- 


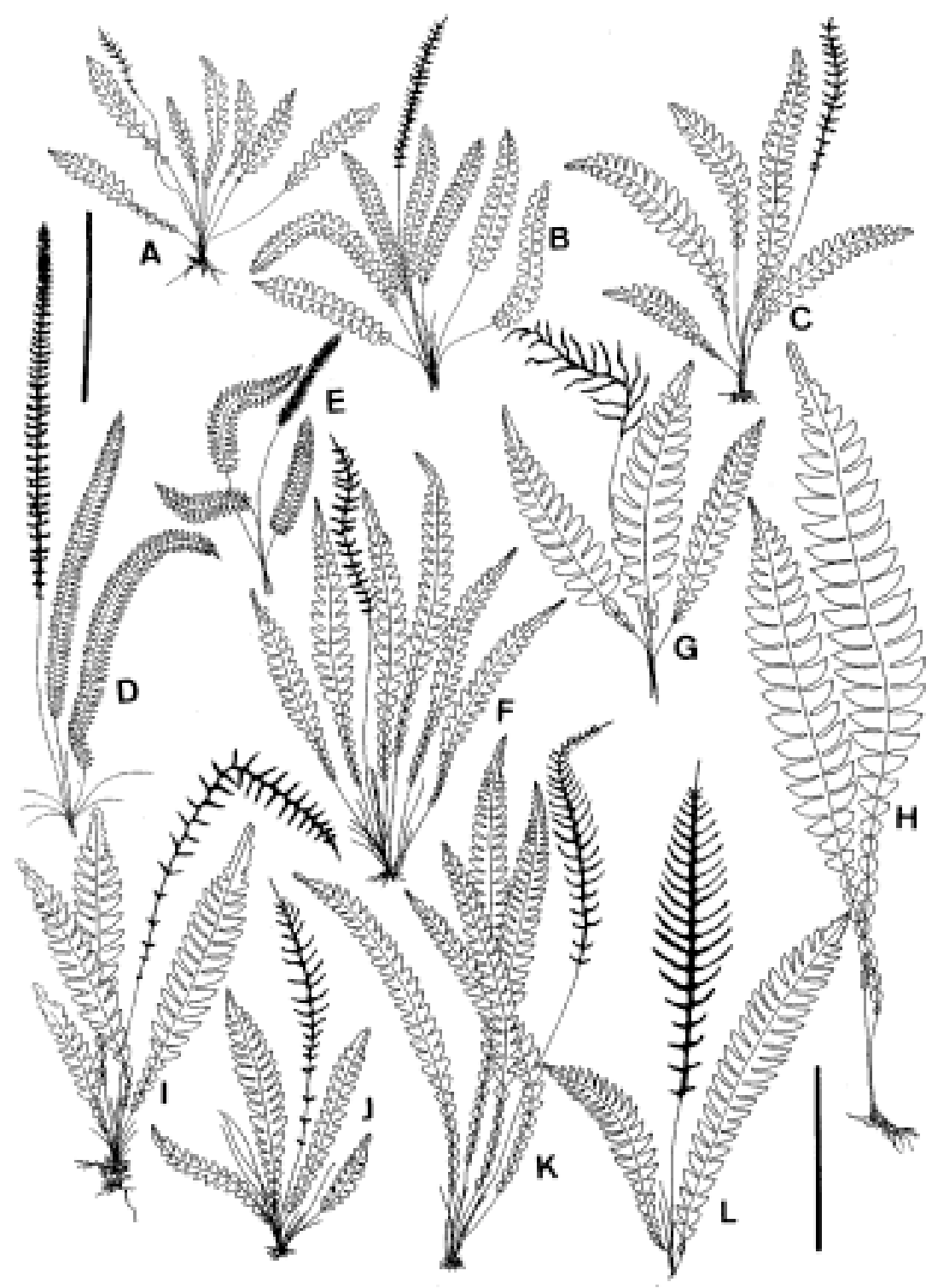

Figura 2. Esporófitos de especies de Blechnum. A: B. corralense, de Corral, Chile, Gunckel 4887 (LP). B: B. penna-marina de Neuquén, Argentina, Debandi 92 (LP). C: B. stoloniferum de Oaxaca, México, Mickel \& Leonard 4661 (LP). D: B. spicant de Coruña, España, Prada s/n (MACB). E: B. microphyllum, de Neuquén, Argentina, Diem 3366 (LP). F: B. blechnoides de Concepción, Chile, de la Sota 6024 (LP). G: B. lehmannii de La Paz, Bolivia, Solomon 16392 (LP). H: B. asperum de Arauco, Chile, Weldt-Rodríguez 1083/378 B (LP). I: B. mochaenum subsp. mochaenum de Neuquén, Argentina, Gentili 814 (LP). J: B. mochaenum subsp. achalense de Salta, Argentina, Cassá et al. 235 (LP). K: B. fernandezianum del Archipiélago de Juan Fernández, Masafuera, Meyer 9437 (LP). L: B. mochaenum subsp. squamipes de Salta, Argentina, Cassá et. al. 255 (LP). Barra = $20 \mathrm{~cm}$ en D-E; 10 $\mathrm{cm}$ en los restantes. 
celulares, hialinos, no engrosados, espaciados, proyectados lateralmente o acroscópicamente en los taxones restantes (fig. $1 \mathrm{X}-\mathrm{Y}$ ).

Las frondas son dimórficas con estípites más o menos aglomerados, erguidos, divergentes o divaricados, especialmente en las estériles. En B. spicant las frondas estériles pueden estar completamente extendidas a ras del sustrato, en forma de roseta y erguidas sólo las fértiles. En las restantes especies las frondas son divergentes, pero no extendidas o apoyadas sobre el sustrato. Las frondas fértiles siempre son erguidas.

Las frondas estériles tienen $10-75 \mathrm{~cm}$ de largo en $B$. spicant (fig. 2 D); $20-40 \mathrm{~cm}$ en $B$. asperum (fig. $2 \mathrm{H}$ ), B. lehmannii (fig. $2 \mathrm{G})$ y B. mochaenum subsp. mochaenum (fig. 2 I); 8-10 cm en $B$. corralense (fig. 2 A); 10-14 cm en B. mochaenum var. achalense (fig. $2 \mathrm{~J}$ ); 6-25 cm en $B$. microphyllum (fig. $2 \mathrm{R}$ ); $10-25 \mathrm{~cm}$ en $B$. fernandezianum (fig. $2 \mathrm{~K}$ ) y B. mochaenum subsp. squamipes (fig. $2 \mathrm{~L}$ ); 7-18 cm en $B$. stoloniferum (fig. $2 \mathrm{C}$ ), $5-45 \mathrm{~cm}$ en $B$. blechnoides (fig. 2 F) y $8-70 \mathrm{~cm}$ en $B$. pennamarina (fig. 2 B). Las bases son rectas y los segmentos no están reducidos en $B$. microphyllum, B. penna-marina y B. spicant , mientras que en el resto de los taxones hay 4-10 pares de segmentos basales aflébicos con láminas reducidas gradualmente hacia la base. El número de pares de pinnas se indica la tabla 1 .

Los estípites de las frondas estériles pueden ser desde casi nulos hasta $1 / 3$ de la longitud total de la fronda y este rasgo puede variar en plantas de la misma especie (tab. 1). Son carnosos y flexibles en $B$. corralense, $B$. microphyllum, B. penna-marina y $B$. stoloniferum y rígidos en el resto de los taxones. Aunque el color no es un rasgo constante y no sería específico, son basalmente oscuros a negruzcos, más claros cerca del raquis o bien castaño-rojizos o amarillentos a pajizos y en los circinos de $B$. penna-marina, B. spicant y B. stoloniferum pueden estar intensamente coloreados de magenta. Son adaxialmente cóncavos en $B$. lehmannii, B. microphyllum, B. mochaenum subsp. mochaenum, B. penna-marina y $B$. spicant y marcadamente canaliculados en el resto de los taxones. La epidermis es siempre papilosa o bien papiloso-pilosa en $B$. corralense, $B$. fernandezianum, $B$. mochaenum subsp. achalense (en esta subespecie con pelos muy esparcidos o caducos) y B. spicant.

Las láminas estériles son imparipinnadas, pinnatífidas a pinnatisectas (figs. 2). Tienen contorno elíptico a oblongoelíptico, con base atenuada y'ápice acuminado en $B$. asperum (fig. $2 \mathrm{H}$ ), $B$. lehmannii (fig. $2 \mathrm{G}$ ), B. mochaenum subsp. mochaenum (fig. 2 I), B. mochaenum subsp. achalense (fig. $2 \mathrm{~J}$ ), B. mochaenum subsp. squamipes (fig. 2 L) y B. stoloniferum (fig. $2 \mathrm{C}$ ); lanceolado a linear-lanceolado, con bases atenuadas y ápices agudos en $B$. blechnoides (fig. 2 F), B. fernandezianum (fig. 2 K) y B. spicant (fig. 2 D); lanceolado lineares, con base recta y ápice más o menos agudo, en $B$. microphyllum (fig. 2 E) y $B$. penna-marina (fig. 2B) y oblanceolado, con base atenuada y ápice romo, en $B$. corralense (fig. $2 \mathrm{~A}$ ).

Los segmentos estériles son opuestos o casi opuestos y se insertan por todo el ancho de su base (fig. 3 A-M). En el tercio apical de la lámina se disponen próximos a imbricados en B. microphyllum, $B$. blechnoides y B. fernandezianum, y son próximos a distantes en el resto de los taxones. Son orbiculares a oblongos, con ápice obtuso, en B. corralense (fig. $3 \mathrm{~A}$ ), $B$. blechnoides (fig. 3 C-D), B. mochaenum subsp. achalense (fig. $3 \mathrm{H}$ ), B. penna-marina (fig. 3 F) y B. stoloniferum (fig. 3 B); son triangulares, con ápice agudo, en $B$. 


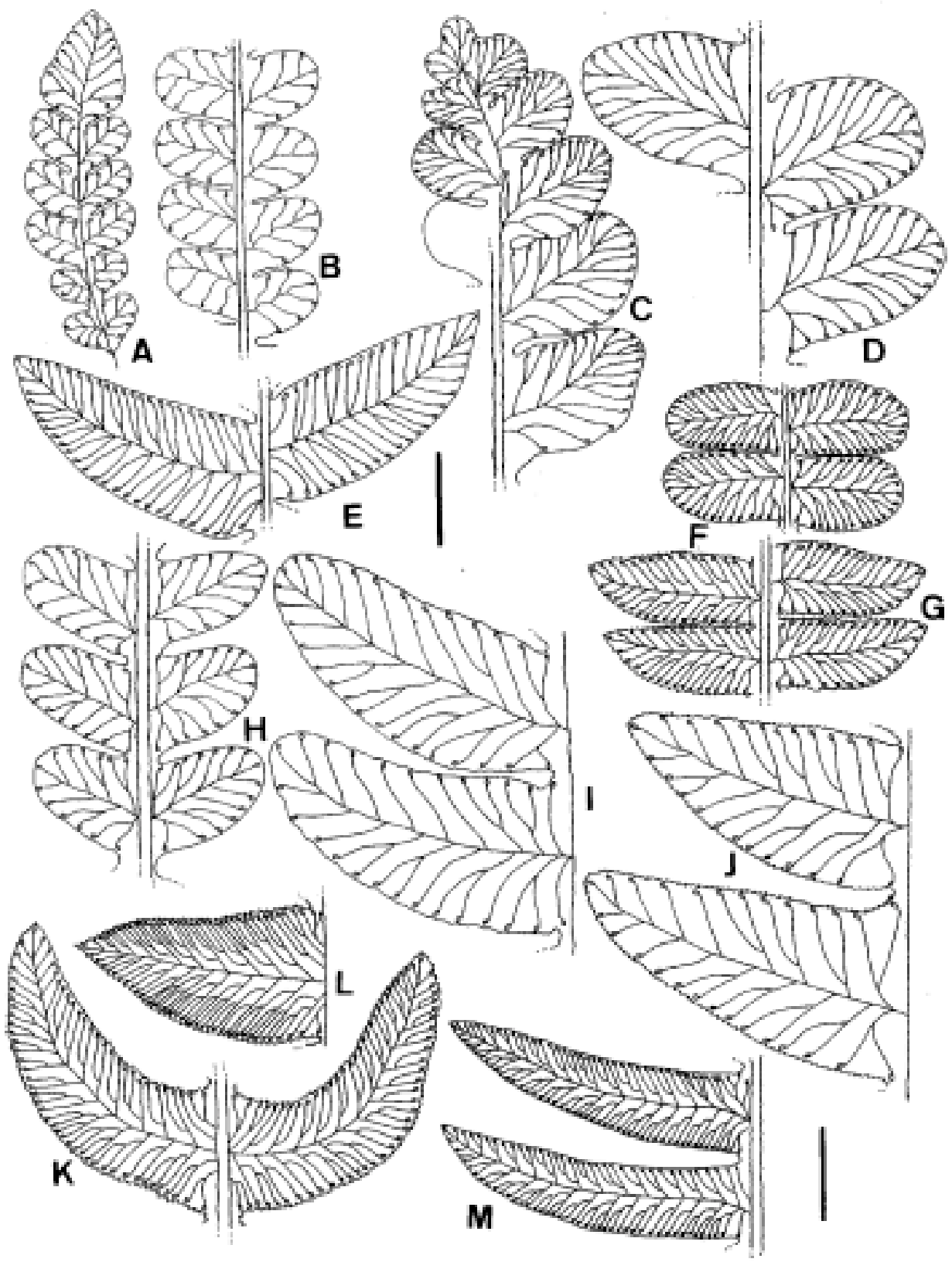

Figura 3. Láminas de los segmentos y venación en especies de Blechnum. A: B. corralense. B: $B$. stoloniferum. C-D: B. blechnoides. E: B. lehmannii. F: B. penna-marina. G: B. microphyllum. H: $B$. mochaenum subsp. achalense. I: B. fernandezianum. J: B. mochaenum subsp. squamipes. K: $B$. mochaenum subsp. mochaenum. L: B. asperum. M: B. spicant. Barra $=1,5 \mathrm{~cm}$ en A-B, F-G ; $1 \mathrm{~cm}$ en C-E y K-M, 0,5 en H-J 
lehmannii (fig. 3 E), B. microphyllum (fig. 3 G) y B. mochaenum subsp. squamipes (fig. 3 J) B. asperum (fig. 3 L), B. mochaenum subsp. mochaenum (fig. $3 \mathrm{~K}$ ) y B. spicant (fig. $3 \mathrm{M}$ ) y triangulares con ápice obtuso en B. fernandezianum (fig. 3 I). La textura es variable en el grupo y su variación se indica en la tabla 1.

La venación es libre pinnada (fig. 3), con venas muy visibles en $B$. fernandezianum y en el hipofilo de $B$. blechnoides e inmersas en los demás taxones. Blechnum corralense y B. stoloniferum presentan venas simples (fig. 3 A- B); $B$. lehmannii venas simples, geminadas $\mathrm{y}$ bifurcadas cerca de la costa (fig. 3 E); $B$. blechnoides (fig. 3 C), B. microphyllum (fig. $3 \mathrm{G)}$ y B. mochaenum subsp. achalense (fig. $3 \mathrm{H}$ ) venas simples y bifurcadas, a veces las simples más abundantes y $B$. penna-marina venas bifurcadas (fig. 3 F). En los demás taxones las venas son bifurcadas, una sola vez en $B$. fernandezianum (fig. 3 I), $B$. mochaenum subsp. squamipes (fig. $3 \mathrm{~J}$ ) y en algunos ejemplares de $B$. mochaenum subsp. mochaenum; dos veces en $B$. asperum (fig. 3 L), la mayoría de las plantas de $B$. mochaenum subsp. mochaenum (fig. $3 \mathrm{~K}$ ) y $B$. spicant (fig. $3 \mathrm{M}$ ). En B. spicant la segunda bifurcación se produce en la rama acroscópica, en B. mochaenum subsp. mochaenum en una o ambas ramas, al azar, en la misma pinna, y en $B$. asperum predominan las dobles bifurcaciones (fig. 3 L). En los segmentos basales aflébicos, la venación es simple.

El indumento superficial de las láminas estériles es relativamente uniforme (figs. 47). Está constituido por pelos uniseriados, 2 -7 celulares, esparcidos sobre venas, láminas y márgenes, y aunque los más frecuentes son los pelos 4-7 celulares, en las láminas coexisten todos los tipos. La célula basal puede ser algo más larga que las del cuerpo y la terminal es similar en longitud a cualquier célula del cuerpo del pelo, excepto en $B$. corralense, que presenta pelos con células terminales $2-3$ veces más largas que las del cuerpo y a veces tan largas como la mitad de la longitud total del pelo (fig. 4 AB). Las células terminales son cilíndricas, capitadas o algo agudas, y en general coexisten todos los tipos, especialmente en B. fernandezianum (fig. 7 F-I). El indumento superficial está ausente en B. blechnoides y $B$. lehmannii; es abundante en $B$. fernandezianum (fig. 7 F-I), moderadamente abundante en $B$. microphyllum, $B$. mochaenum subsp. mochaenum (fig. 6 D-E) y más escaso en los demás taxones, con excepción de $B$. asperum. En esta especie la epidermis está erizada de acúleos unicelulares, cortos, agudos, muy engrosados, distribuidos entre los estomas y sobre las venas, y además, se presentan pelos setiformes unicelulares rígidos, largamente cónicos y con pared engrosada (fig. 8 F-H). Los pelos setiformes aparecen también en $B$. mochaenum subsp. mochaenum (fig. 6 C-D), pero son esporádicos, mucho más delgados, fláccidos y menos engrosados que los de $B$. asperum.

Los márgenes de los segmentos son enteros en B. blechnoides, B. lehmannii y $B$. spicant; ondulados a subrepandos en $B$. corralense, en $B$. fernandezianum y $B$. stoloniferum; crenados, subpapilosos en $B$. mochaenum subsp. achalense y $B$. pennamarina; denticulados en $B$. asperum, $B$. microphyllum, B. mochaenum subsp. mochaenum y B. mochaenum subsp. squamipes. Estructuralmente, son subpapilosos en B. corralense; papilosos, con papilas engrosadas, en 1-2 hileras, en $B$. penna-marina (fig. $5 \mathrm{~F}$ ), papilosos, con elementos celulares hialinos con paredes delgadas, dispuestos en una o más hileras, en $B$. fernandezianum y denticulados en $B$. asperum (fig. 8 I), B. microphyllum (fig. 5 C), B. mochaenum subsp. mochaenum (fig. 


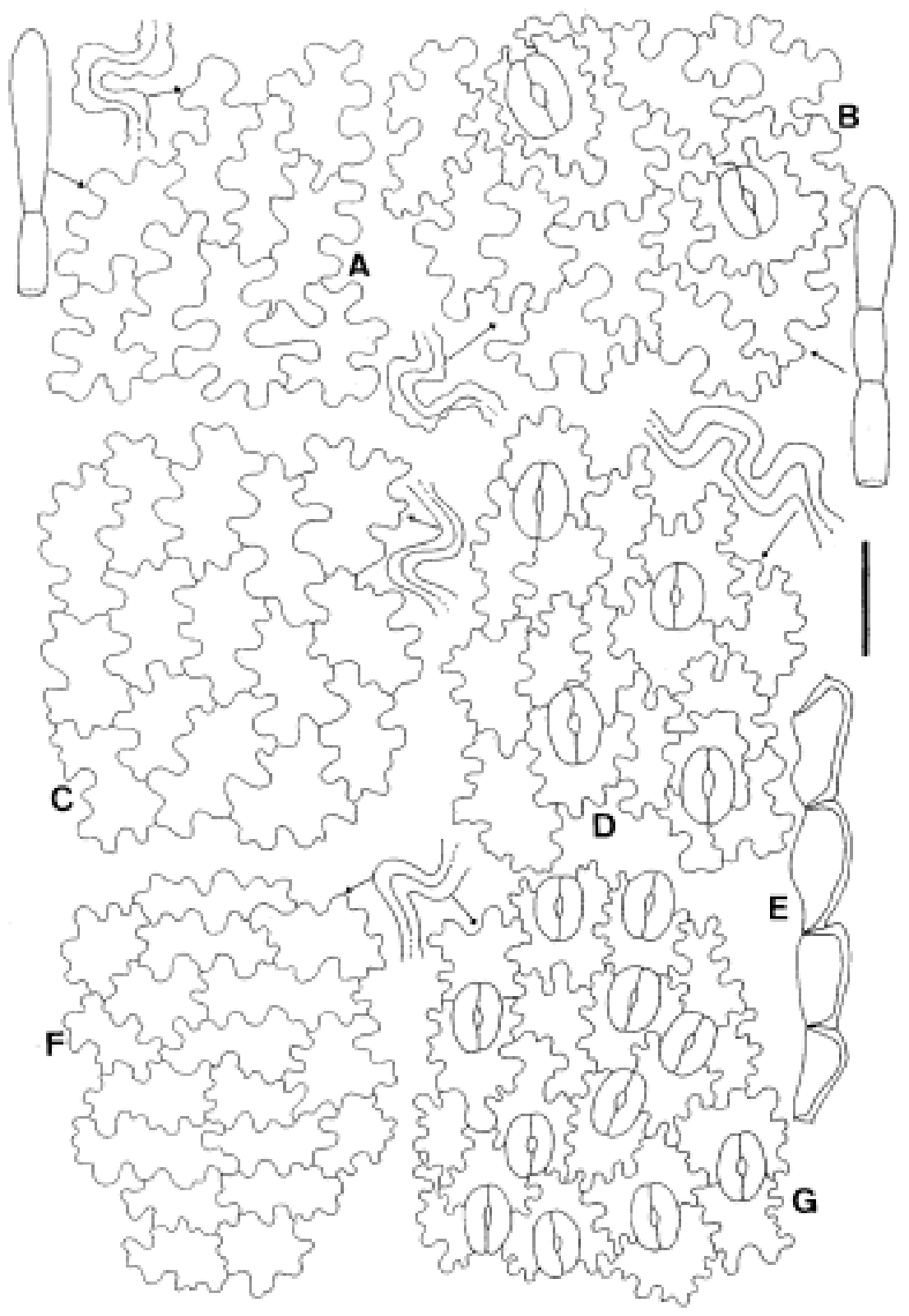

Figura 4. Modelos epidérmicos, engrosamientos parietales de las células, márgenes y pelos superficiales en especies de Blechnum. A-B: B. corralense. C-D: B. blechnoides. F-G: B. lehmannii. E: Margen en $B$. corralense. Izquierda, epifilos; derecha, hipofilos. Barra $=200 \mu \mathrm{m}$ en pelos; $100 \mu \mathrm{m}$, en células epidérmicas y margen; $50 \mu \mathrm{m}$ en detalle de engrosamientos parietales. 
$6 \mathrm{H})$, B. mochaenum subsp. achalense y $B$. mochaenum subsp. squamipes (fig. $6 \mathrm{G}$ ). El denticulado marginal varía: en $B$. mochaenum var. achalense los dentículos se presentan en una sola hilera, son más bien romos, translúcidos y delicados; en $B$. mochaenum subsp. squamipes se forman hasta 3 hileras, son prominentes, subagudos o romos, poco engrosados y hialinos, mientras que en' $B$. asperum (fig. 8 I), $B$. microphyllum (fig. 5 C) у B. mochaenum subsp. mochaenum (fig. $6 \mathrm{H}$ ) son agudos, incurvados o acroscópicamente dirigidos y presentan paredes muy engrosadas.

Los modelos epidérmicos son sinuosos y las células tienen relaciones largo/ancho diferentes en los taxones (figs. 4-8). En general son más largas que anchas tanto en epifilos como en hipofilos. El radio celular se aprecia mejor en los epifilos, por la ausencia de estomas y en general varía en el rango de 2-4:1. Las paredes tienen sinuosidades irregulares y predominan las ondas curvas, simples o compuestas, es decir, con otras ondas en los senos y/o cimas. Sólo se observaron sinuosidades poco marcadas y algo angulosas en B. mochaenum subsp. achalense (fig. 7 A- B). En la mayoría de los taxones las ondas son similares en la pared primaria y la lámina media, pero ambas paredes pueden presentar diferencias de ondulación (figs. 4 A, 5 A, 6 E). Los epifilos e hipofilos de $B$. corralense (fig. 4 A-B), $B$. blechnoides (fig. $4 \mathrm{C}-\mathrm{D}$ ), B. lehmannii (fig. 4 F-G) y B. mochaenum subsp. squamipes (fig. $6 \mathrm{E}-\mathrm{F}$ ) tienen sinuosidades simples, profundas y amplias. En el resto de los taxones predominan las sinuosidades frecuentes, compuestas de sinuosidades menos profundas. Las epidermis más características en este aspecto son las de $B$. penna-marina (fig. 5 D-E, G-H), $B$. mochaenum subsp. mochaeum (fig. 6 A-D), B. fernandezianum (fig. 7 D-E), B. spicant (fig. 8 C-D) y B. asperum (fig. 8 G-H). Las epidermis de B. microphyllum (fig. 5 A-B) y $B$. penna-marina (fig. $5 \mathrm{D}-\mathrm{E}$ ) son bastante similares, pero $B$. microphyllum tiene las células más pequeñas, las sinuosidades más frecuentes y los engrosamientos parietales más irregulares de todos los taxones estudiados. Las subespecies de $B$. mochaenum se diferencian bien por su modelo epidérmico. Los modelos de $B$. fernandezianum, $B$. lehmannii y $B$. mochaenum subsp. squamipes son similares pero B. fernandezianum tiene las paredes más delgadas del grupo. El modelo epidérmico de $B$. mochaenum subsp. achalense se caracteriza por las ondas someras y angulosas y las paredes relativamente delgadas, sin engrosamientos en curvas o ángulos (fig. 7 A-C). Las células de mayor tamaño se observaron en los epifilos de $B$. blechnoides (fig. 4 C), $B$. corralense (fig. 4 A) y B. stoloniferum (fig. 8 A). En tres ejemplares de B. penna-marina, uno de Neuquén (Gómez Rozas 503 LP) y dos de Tierra del Fuego (Torres 1122 LP; Maldonado s. $n$. LP) y dos ejemplares de $B$. mochaenum subsp. mochaenum, uno de Chubut (Roig et al. 13907 LP) y otro de Neuquén (Diem 1192 LP), se observaron células epidérmicas y estomas de tamaño mayor que el registrado para el resto de los ejemplares estudiados de cada especie, condición que también se presentó en los estomas y en las esporas de esos ejemplares (tab. 1).

Rodríguez Ríos (1973) estudió las epidermis de plántulas de $B$. microphyllum y $B$. penna-marina e ilustra sinuosidades menos pronunciadas que las vistas aquí en material adulto de esas especies, lo que podría interpretarse como un fenómeno natural de plantas juveniles. La fase en que se adquiere el modelo adulto puede variar en especies de un mismo género y sólo un estudio ontogenético del desarrollo del modelo, desde el circino y la etapa tenueral 


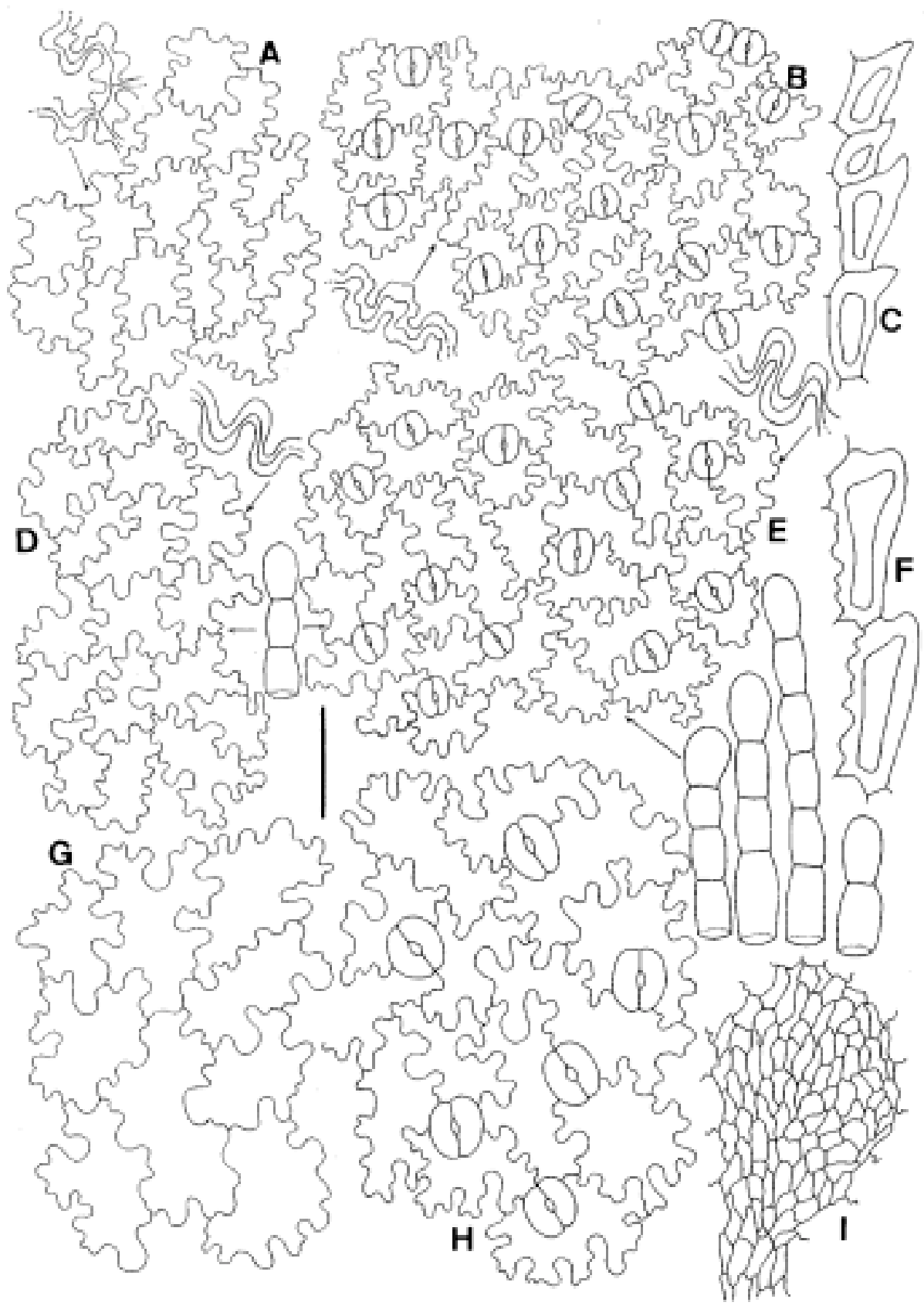

Figura 5. Modelos epidérmicos, engrosamientos parietales de las células, márgenes, pelos superficiales e hidatodos en especies de Blechnum. A-C: B. microphyllum. C: Margen denticulado. D-F: B. pennamarina (generalizado). F: Margen papiloso. G-H: B. penna-marina de Neuquén, Argentina, Gómez \& Rosas 503 (LP). I: Hidatodo. Izquierda, epifilos; derecha, hipofilos. Barra $=200 \mu \mathrm{m}$ en pelos e hidatodo; $100 \mu \mathrm{m}$, en células epidérmicas y margen; $50 \mu \mathrm{m}$ en detalle de engrosamientos parietales. 
hasta la fronda adulta permite deducir si el modelo adulto se establece tempranamente o no (Rolleri, 2004). En B. spicant el modelo adulto se establece muy tempranamente y en algunas comunidades hay plantas de 10-12 $\mathrm{cm}$ que presentan sólo frondas fértiles, con una porción laminar moderadamente desarrollada, en las cuales los esporangios son normales y el modelo epidérmico es el adulto de la especie. En otras especies la condición es diferente y casi opuesta: en $B$. cordatum el tipo adulto de sinuosidad y el espesor máximo de las paredes de las células epidérmicas se alcanzan en plantas de 40-60 $\mathrm{cm}$, mientras que durante el desarrollo de la fronda las sinuosidades van variando paulatinamente desde las células poligonales de los circinos, las subsinuosas de las plántulas y las moderadamente sinuosas de plantas de 25-30 cm de altura (Prada \& Rolleri, datos no publicados). El modelo epidérmico encontrado en $B$. mochaenum subsp. achalense, con sinuosidades someras, curvas y angulosas, difiere de otros modelos, tanto de los taxones del grupo B. pennamarina como de taxones otros grupos de Blechnum y podría sugerir una forma juvenil. Las colecciones de B. mochaenum subsp. achalense son muy escasas, las plantas están estériles y aparecen mezcladas con plantas maduras de B. mochaenum subsp. squamipes.

Los estomas tienen contornos elípticos a sub-orbiculares y están rodeados por células vecinas, es decir, que no difieren de las restantes epidérmicas (Rolleri et al., 1987), pero se encuentran en disposiciones características: dos células orientadas perpendicularmente respecto de las oclusivas; tres células, en general una de tamaño algo menor, o bien 4-5 células, rodeando los estomas. Es decir, en la mayoría de los taxones estudiados los estomas son diacíticos, anomocíticos y, más raramente, anisocíticos (Prabhakar, 2003). En los diacíticos una de las dos células que rodean al estoma tiene mayor tamaño que la opuesta. En $B$. corralense (fig. 4 B), $B$. fernandezianum, B. mochaenum subsp. mochaenum (fig. 6 B) y B. mochaenum subsp. achalense (fig. 7 C) es frecuente la presencia de dos células envolventes, más o menos paralelas, opuestas a una más pequeña. Las dimensiones y densidades estomáticas se dan en la tabla 1. En tres ejemplares de $B$. penna-marina y dos de $B$. mochaenum subsp. mochaenum ya citados se hallaron estomas que eventualmente duplican el tamaño promedio común en esos taxones, por lo que podría tratarse de individuos poliploides.

Los hidatodos epifílicos son comunes a todas los taxones estudiados. Son grandes, algo sobresalientes, tienen contorno elíptico ancho, espatulado o redondeado, excepto en B. spicant, en que son pequeños, angostamente elípticos y casi inmersos. En todos los casos, las células glandulares que los forman tienen paredes rectas y no sinuosas como las epidérmicas adyacentes (fig. 5 I). Haberlandt (1965) mencionó los hidatodos para muchos helechos, particularmente Polypodiaceae s. l. y los consideró activos en relación con la capacidad secretora de sus células, directamente ubicadas sobre las porciones terminales de las venas. Ogura (1972) citó estas estructuras para otros pteridófitos, como Dryopteris Adans., Drymoglossum C. Pres1, Nephrolepis Schott y muchas Polypodiaceae, además de Blechnum. Sperry (1983) estudió la morfología y funcionamiento de los hidatodos de $B$. lehmannii. Chambers \& Farrant (1996 b) los mencionaron como "dark glands", visibles en material de herbario de B. blechnoides. Durán (1997) ilustró los de B. microphyllum, $B$. mochaenum subsp. mochaenum y $B$. penna-marina y los mencionó también para $B$. arcuatum J. Rémy \& Fée y B. tabulare, 


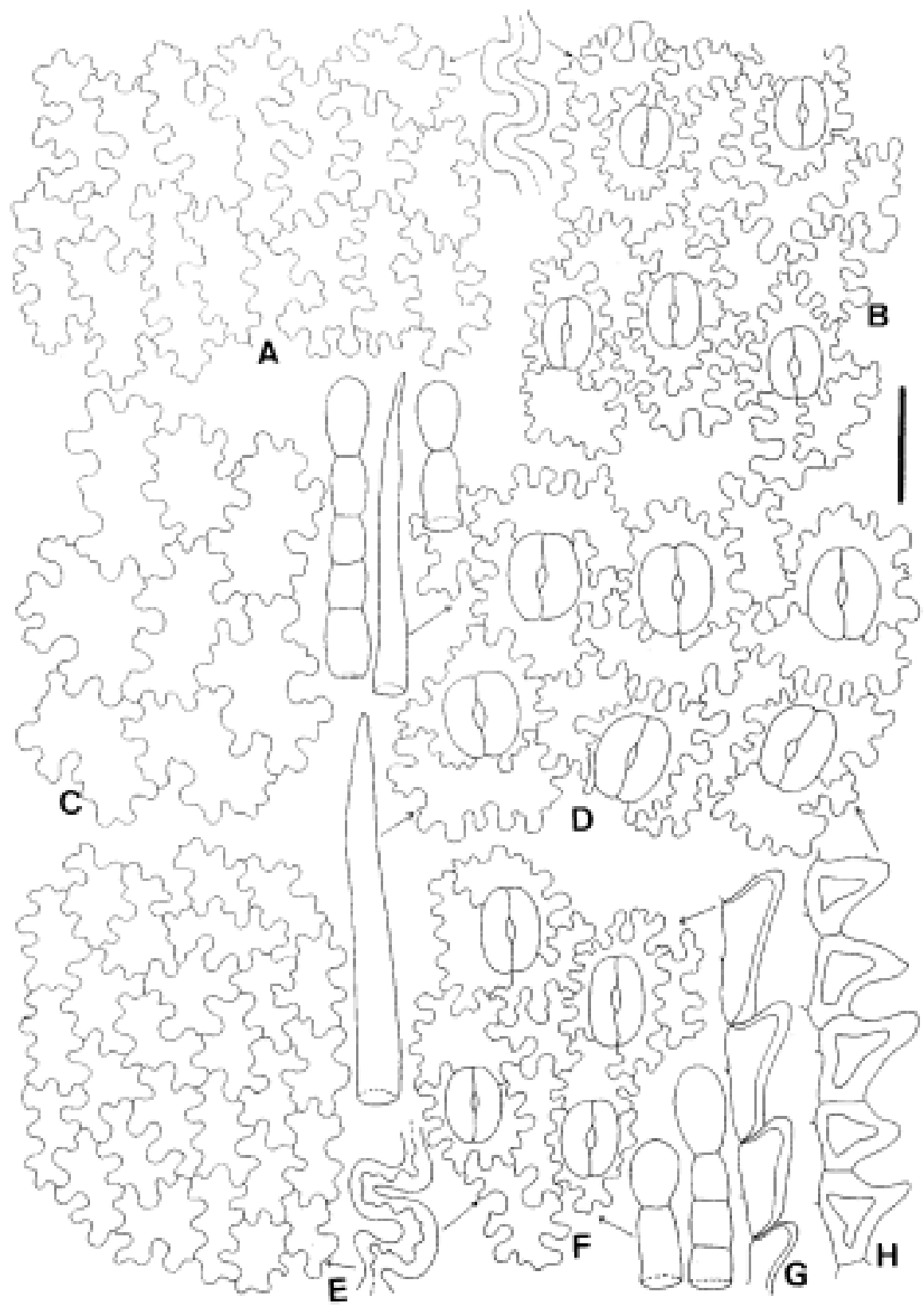

Figura 6. Modelos epidérmicos, engrosamientos parietales de las células, márgenes y pelos superficiales en especies de Blechnum. A-B: B. mochaenum subsp. mochaenum (generalizado). C-D: B. mochaenum subsp. mochaenum de Neuquén, Argentina, Diem 1192 (LP). E-G: B. mochaenum subsp. squamipes. $\mathrm{H}$ : Margen denticulado, con dentículos engrosados, en B. mochaenum subsp. mochaenum. Izquierda, epifilos; derecha, hipofilos. Barra $=200 \mu \mathrm{m}$ en pelos; $100 \mu \mathrm{m}$, en células epidérmicas y margen; 50 $\mu \mathrm{m}$ en detalle de engrosamientos parietales. 
señalando que en las especies de Argentina no se han utilizado como rasgo diagnóstico. Sin embargo, de la Sota (1977) ya había considerado que podrían ser un carácter de grupo de especies al analizar B. mochaenum y describir sus variedades. Oliveira Dittrich (2005) los citó para B. lehmannii y para $B$. divergens, en material del S y SE de Brasil.

Las secciones transversales de los estípites son muy similares en frondas estériles y fértiles. Son más o menos cóncavo-convexas en $B$. spicant, $B$. lehmannii, $B$. mochaenum subsp. mochaenum, $B$. penna-marina y $B$. microphyllum (fig. 9 A-E) y más marcadamente canaliculadas en $B$. asperum, $B$. blechnoides, $B$. corralense, $B$. fernandezianum, B. mochaenum subsp. achalense, B. mochaenum subsp. squamipes y B. stoloniferum (fig. 9 G-L). Internamente, se observan los tejidos siguientes: una epidermis, un área hipodérmica, constituida por varias capas de células de sostén esclerosadas con aspecto de fibras y un área interna de células parenquimáticas vivas, con paredes delgadas, en la que también se encuentran los haces vasculares. La epidermis es subpapilosa y con una cutícula irregularmente estriada en $B$. lehmannii (fig. 9 S), marcadamente papilosa en todos los taxones restantes (fig. $9 \mathrm{M}-\mathrm{R}, \mathrm{U}-\mathrm{W}$ ) y además tiene pelos en $B$. corralense, $B$. fernandezianum y B. spicant (fig. $9 \mathrm{M}, \mathrm{V}$ y $Q$ respectivamente). Las paredes externas de las células epidérmicas están muy engrosadas y cutinizadas, en algunas especies con varias capas cuticulares claramente superpuestas, como es el caso de B. asperum (fig. 9 R), B. blechnoides y $B$. lehmannii (fig. 9 S). Por debajo de la epidermis se desarrolla una zona de células lignificadas con aspecto de fibras que tiene 1-2 (3) capas de espesor en B. corralense (fig. 9 M), 2-5 capas en B. microphyllum (fig. 9 N), B. mochaenum subsp. squamipes (fig.
9 U), B. mochaenum subsp. achalense y $B$. penna-marina (fig. 9 O), 4-6 capas en $B$. stoloniferum (fig. 9 P), 8-10 capas en $B$. fernandezianum (fig. $9 \mathrm{~V}$ ) , B. mochaenum subsp. mochaenum (fig. $9 \mathrm{~W}$ ) y B. spicant (fig. 9 Q) y hasta 12-15 capas de espesor o más en B. asperum y B. lehmannii (figs. $9 \mathrm{R}$ -S). Los tejidos parenquimáticos que se encuentran por debajo de la zona fibrosa están formados por células grandes, con paredes muy delgadas, dispuestas con espacios intercelulares de amplitud variable y pueden contener gran cantidad de almidón. En B.corralense, B. lehmannii (fig. 9 S), B. mochaenum subsp. mochaenum (fig. 9 W) y B. mochaenum subsp. squamipes, el almidón es muy abundante y aparece incluso en el lumen aún funcional de las células de aspecto fibroso de las capas más internas y alejadas de la epidermis, mientras que es muy escaso o está ausente en los demás taxones. Los granos son simples, más o menos ovoides, de contorno oblongo, elíptico o subcircular. No hay menciones del almidón en la bibliografía existente.

Las protuberancias intercelulares pécticas, PIP, (Potgieter \& van Wyk, 1992; Rolleri et al., 1999; Prada \& Rolleri, 2005) se presentan como verrugas y/o filamentos capitados muy cortos, en el parénquima de los estípites de las frondas estériles y fértiles, en el raquis de las frondas fértiles y ocasionalmente en el mesofilo de las frondas estériles. En B. asperum, $B$. corralense, B. mochaenum subsp. achalense, $B$. spicant y $B$. stoloniferum no se encontraron PIP (Tabla 1). Las PIP están poco estudiadas en Blechnum. Fueron citadas por primera vez por Gardiner (1885), Mangin (1893) y Luerssen (1875), para B. brasiliense, $B$. cartilagineum y $B$. procerum, como verrugas pécticas localizadas en los estípites.

En todos los taxones del grupo los estípites presentan tres haces vasculares de tamaño más o menos similar o bien uno más pequeño que los otros dos, como en $B$. 


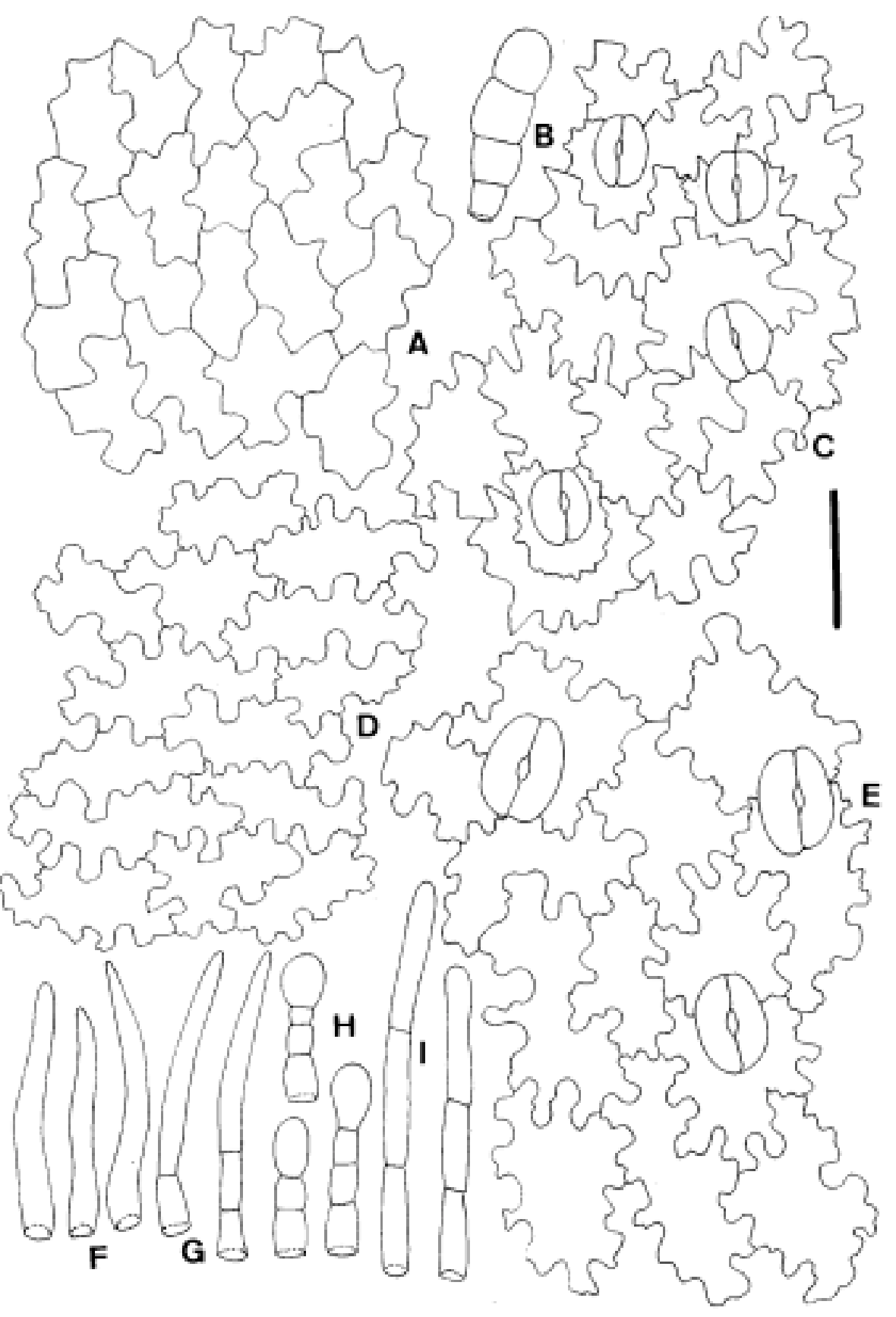

Figura 7. Modelos epidérmicos y pelos superficiales en especies de Blechnum. A-C: B. mochaenum subsp. achalense. D-I: B. fernandezianum. Izquierda, epifilos; derecha, hipofilos. Barra= $200 \mu \mathrm{m}$ en pelos; $100 \mu \mathrm{m}$ en epidermis. 

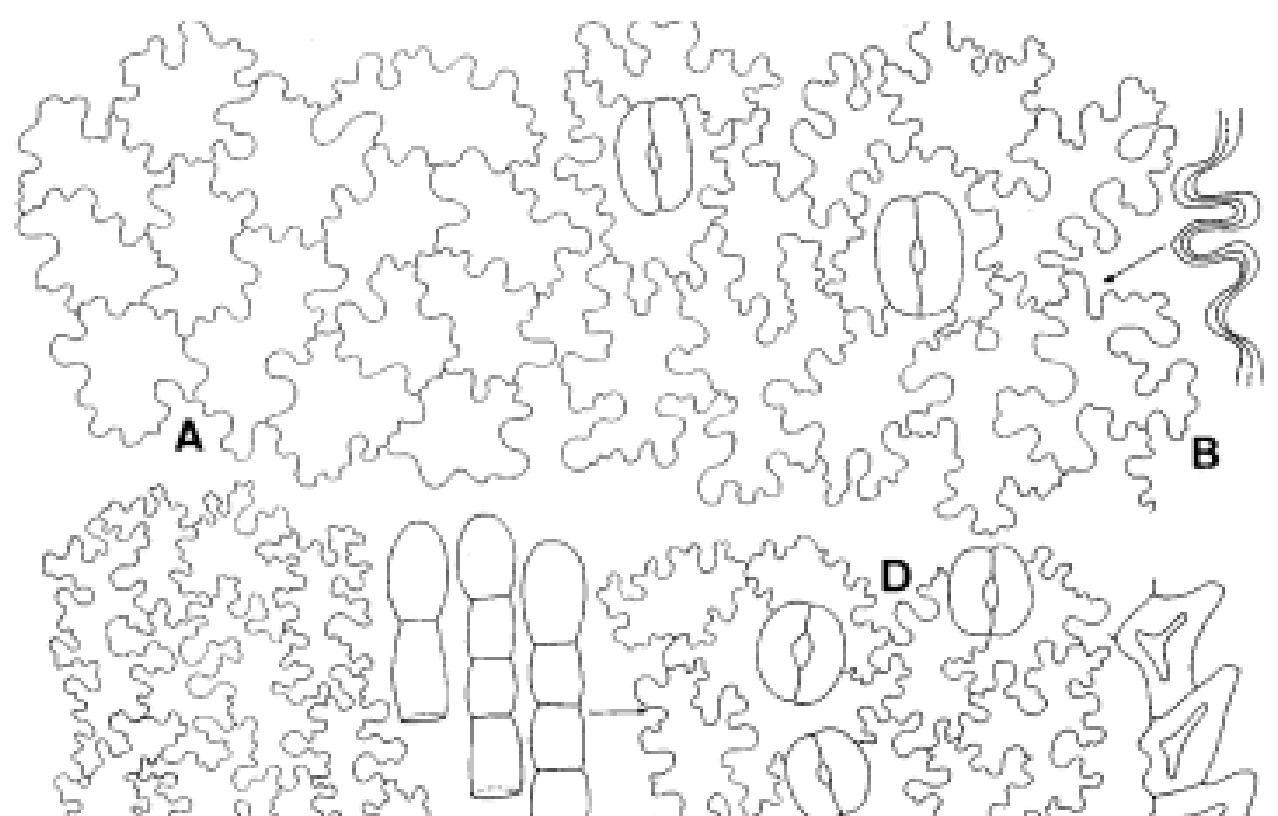

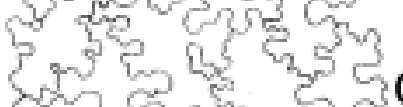

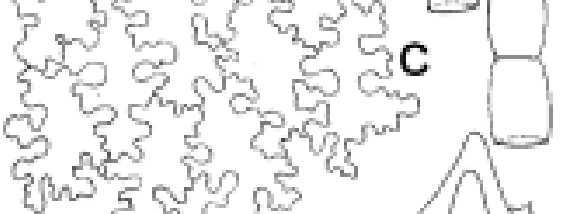

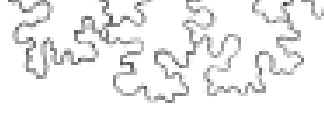

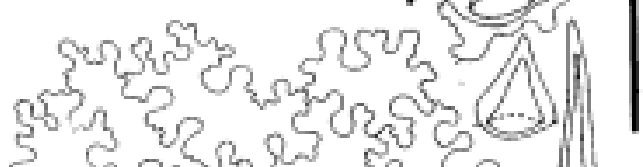

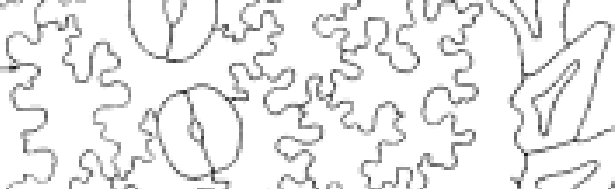

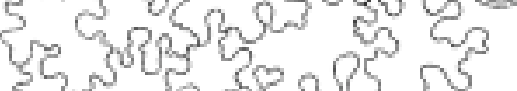

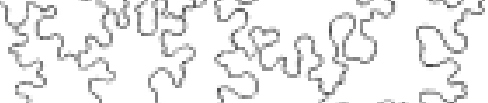

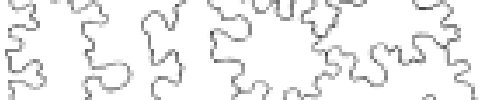

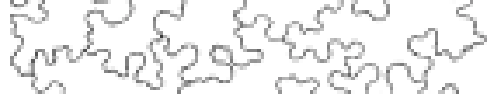

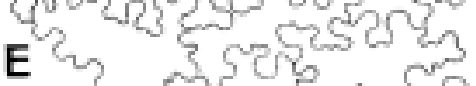

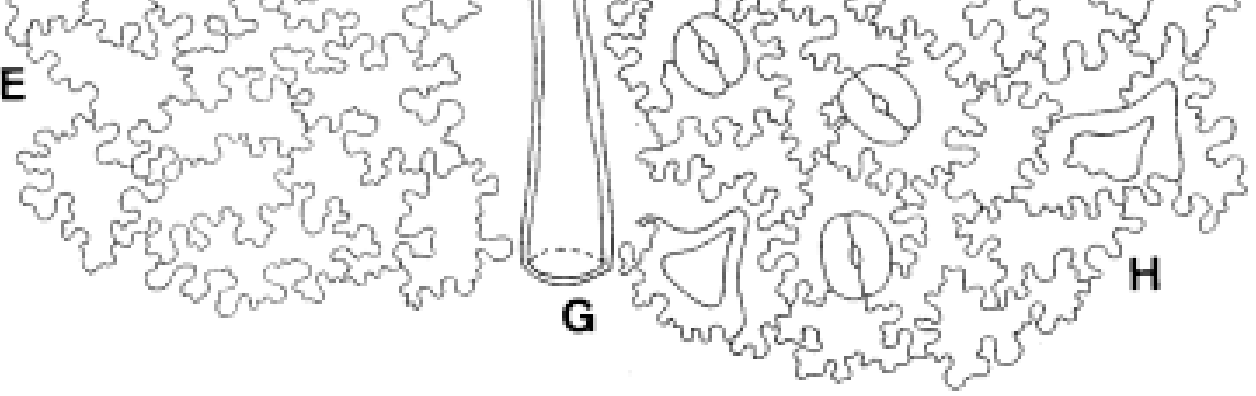

Figura 8. Modelos epidérmicos, engrosamientos parietales de las células, márgenes y pelos superficiales en especies de Blechnum. A-B: B. stoloniferum. C-D: B. spicant. E-I: B. asperum. Izquierda, epifilos; derecha, hipofilos. Barra $=200 \mu \mathrm{m}$ en pelos; $100 \mu \mathrm{m}$ en células epidérmicas y margen; $50 \mu \mathrm{m}$ en detalle de engrosamientos parietales. 


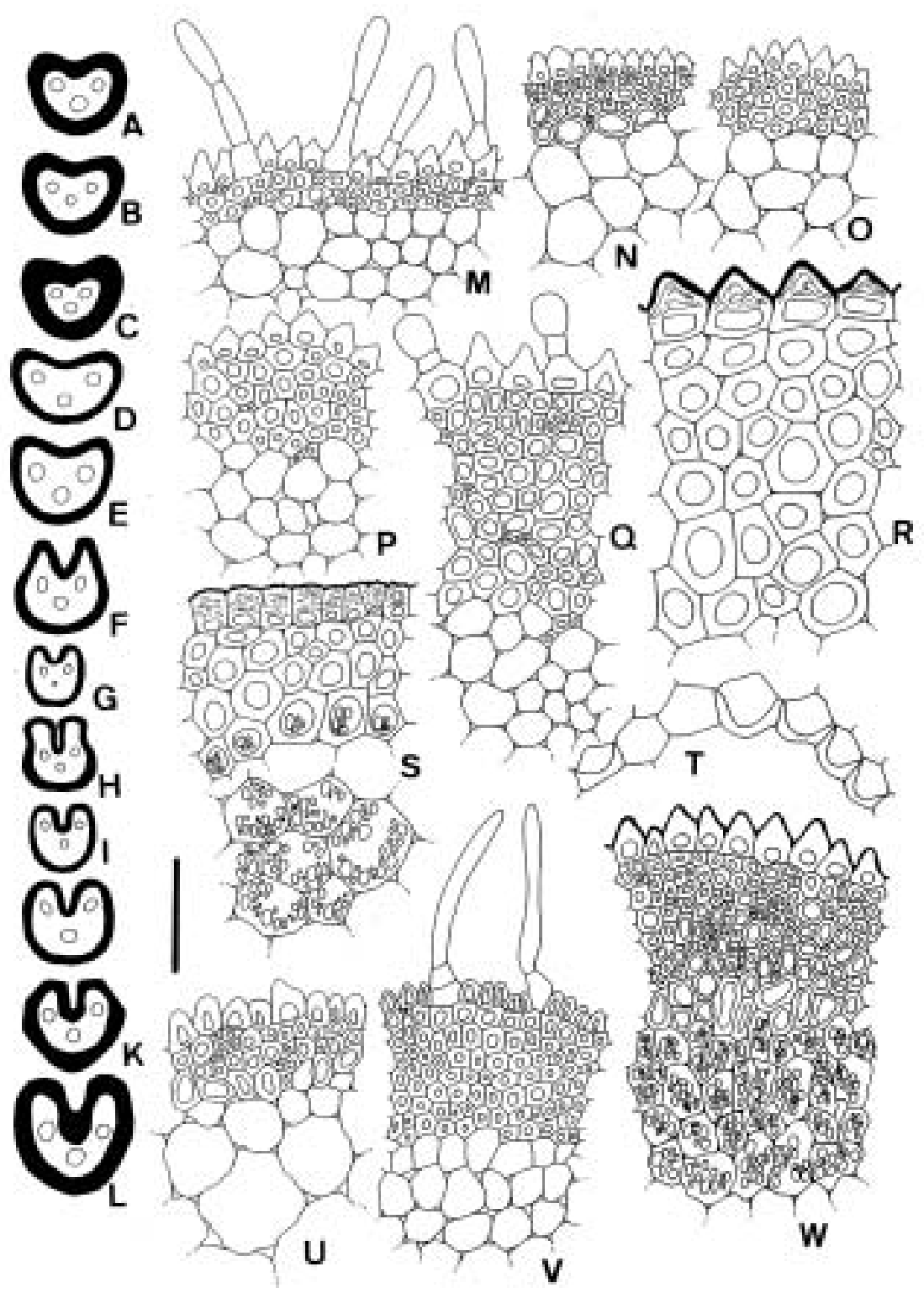

Figura 9. Seccciones transversales de estípite en especies de Blechnum. A-L: Contorno de las secciones. M-W: Detalle de la anatomía de las secciones del estípite. A, Q: B. spicant. B, S: B. lehmannii. C, W: B. mochaenum subps. mochaenum. D, O: B. penna-marina. E, N: B. microphyllum. F, V: B. fernandezianum. G, U: B. mochaenum subps. achalense. H: B. mochaenum subps. squamipes. I, P: B. stoloniferum. J, M: B. corralense. K, R: B: asperum. L: B. blechnoides. T: Endodermis en U, generalizada. En R y S, representado sólo un tercio del área hipodérmica fibrosa. af, área hipodérmica fibrosa; al, almidón; $\mathrm{cp}$, células de pasaje; $\mathrm{p}$, parénquima no amiláceo; pe, pelos epidérmicos del estípite; pp, papilas epidérmicas. Barra $=1 \mathrm{~mm}$ en A-I, K-L; 0,5 mm en J; $100 \mu \mathrm{m}$ en M-S, U-W; 50 $\mu \mathrm{m}$ en $\mathrm{T}$. 
mochaeum subsp. achalense (fig. 9 G) ; están rodeados por una endodermis con engrosamientos en $U$ muy marcados $y$ células de pasaje, solitarias o en pares (fig. $9 \mathrm{~T}) \mathrm{y}$, frecuentemente, por 3-4 capas de células con paredes engrosadas, no lignificadas, con las paredes levemente impregnadas de taninos. La presencia y desarrollo de esta zona circunfascicular es variable y no se observó en los estípites de B. corralense, B. microphyllum, B. pennamarina y B. stoloniferum. Ogura, (1972), Duncan \& Issaac (1986) y Moran (1995) señalan la presencia de más de 3 haces vasculares en los estípites de Blechnum. Bercu (2000) menciona la presencia de dos haces en B. spicant y ese autor correlaciona el tamaño del cormo, el bajo número de meristelas en las dictiostelas del rizoma y estípite de muchos helechos (entre ellos $B$. spicant), con las características del habitat y sugiere que los cormos pequeños a medianos que crecen expuestos sobre sustratos rocosos presentan pocos haces. Sin embargo, en el grupo B. penna-marina, los taxones tienen siempre tres haces en el estípite, ya sean terrestres o saxícolas, con cormos pequeños o medianos, crezcan en selvas bajas, de neblina, bosques hiperhúmedos o bosques húmedos perturbados, en suelos ácidos y turbosos de zonas frías subantárticas o neutros.

Las frondas fértiles son más largas que las estériles en todos los taxones estudiados, con excepción de B. asperum, que puede presentar la condición inversa. Forman un conjunto aglomerado, calatiforme en casi todas lo taxones excepto en B. spicant, especie en la que las estériles son frecuentemente arrosetadas y las fértiles siempre erguidas. En B. lehmanni las frondas se insertan algo más espaciadas, pero el rizoma se yergue y el aspecto es calatiforme, muy similar a las plantas de B. mochaneum subsp. mochaenum.
Los estípites de las frondas fértiles tienen una longitud igual o mayor que la longitud de la porción esporógena. El color es castaño oscuro en la base, luego amarillento en B. microphyllum; amarillo claro a ocráceo en $B$. mochaenum var. achalense; castaño oscuro en B. blechnoides y B. mochaenum subsp. mochaenum; castaño oscuro purpúreo, casi negro en $B$. pennamarina y $B$. spicant; castaño claro en' $B$. mochaenum subsp. squamipes, castaño rojizo en $B$. fernandezianum y purpúreo en' $B$. stoloniferum, aunque esta coloración puede variar. La epidermis es igual a la de los estípites estériles y el parénquima interno de los estípites de la frondas fértiles de $B$. corralense $y$ B. mochaenum subsp. mochaenum reservan almidón.

Las láminas fértiles siempre están muy contraidas, son más cortas o tan largas como las estériles (B. fernandezianum, B. lehmannii, $B$. mochaenum subsp. mochaenum, $B$. mochaenum subsp. squamipes y $B$. mochaenum subsp. achalense). La venación es simple o bifurcada, con venas separadas. Presentan cenosoros continuos, con indusios que se extienden desde la base de las pinnas hasta su porción subapical, que por lo general, carece de esporangios y se observa como una lengüeta estéril de unos 2-5 $\mathrm{mm}$.

Los indusios tienen 0,2-0,5 $\mathrm{mm}$ de anchura y no presentan pelos ni células coloreadas o glandulares. El margen es entero en B. spicant (fig. $10 \mathrm{~A}, \mathrm{I})$ y $B$. stoloniferum (fig. $10 \mathrm{~B}, \mathrm{~J}$ ), ondulado uniforme en B. mochaenum subsp. achalense (fig. $10 \mathrm{D}, \mathrm{M}$ ), ondulado irregular en $B$. blechnoides (fig. $10 \mathrm{G}, \mathrm{O}$ ), irregularmente eroso a eroso-denticulado en B. lehmannii, $B$. microphyllum (fig. 10 C, L), $B$. mochaenum subsp. mochaenum (fig. $10 \mathrm{C}$, $\mathrm{K})$ y B. mochaenum subsp. squamipes (fig. 10 C-E, K-L, N) e irregularmente laciniadofimbriado en B. penna-marina (fig. $10 \mathrm{H}, \mathrm{P}$ ). Las células epidérmicas de los indusios 


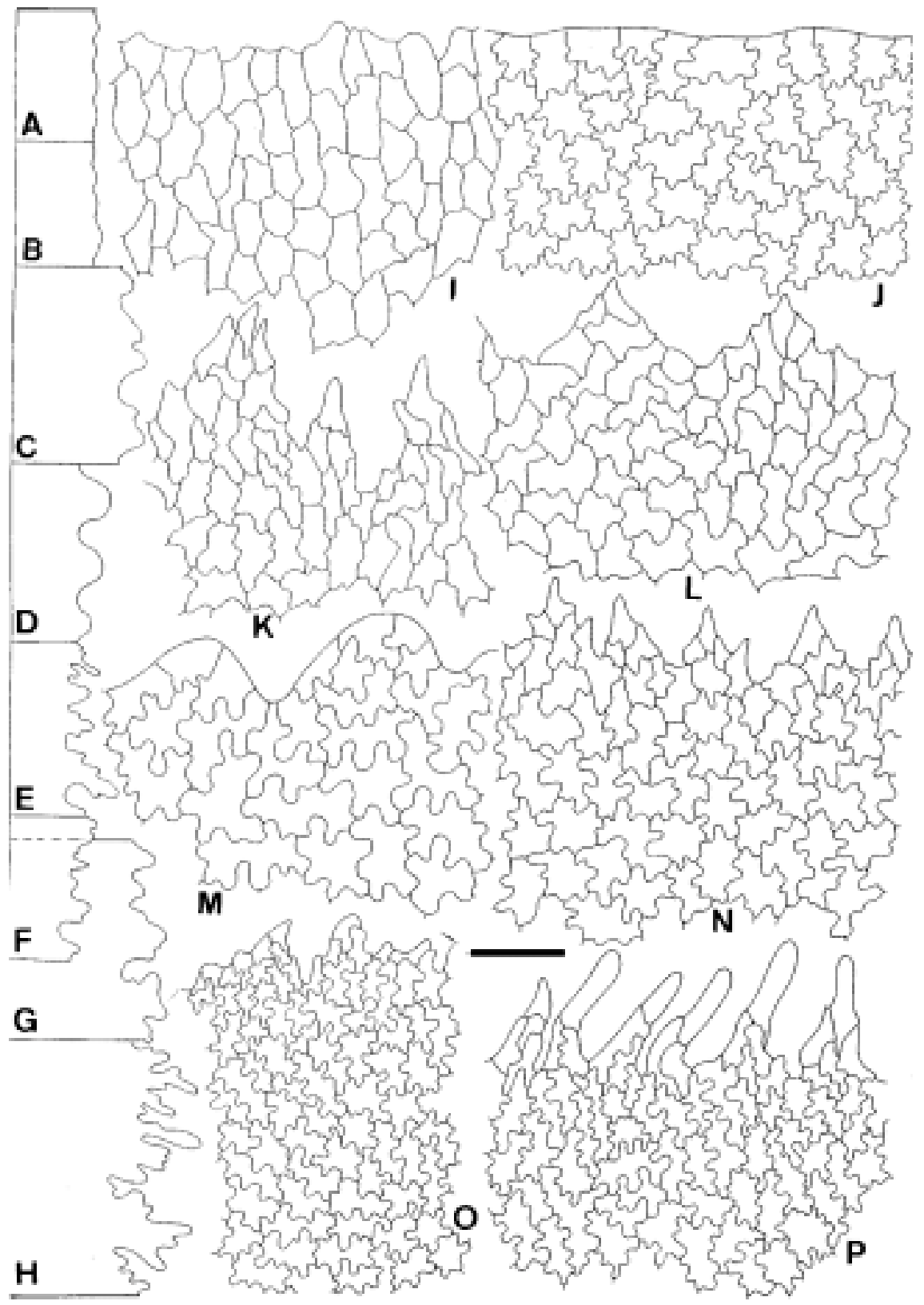

Figura 10. Indusios en especies de Blechnum. A-H: Vista superficial de una porción del indusio mostrando el perfil de los márgenes. I-P: Modelos epidérmicos y detalle de la morfología de los márgenes. A, I: B. spicant. B, J: B. stoloniferum. C, K: B. mochaenum subsp. mochaenum (B. fernandezianum similar). D, M: B. mochaenum subsp. achalense. E, N: B. mochaenum subsp. squamipes. F, L: B. microphyllum. G, O: B. blechnoides. H, P: B. penna-marina. Barra=0,5 mm en A-H; $200 \mu \mathrm{m}$ en I-P. 


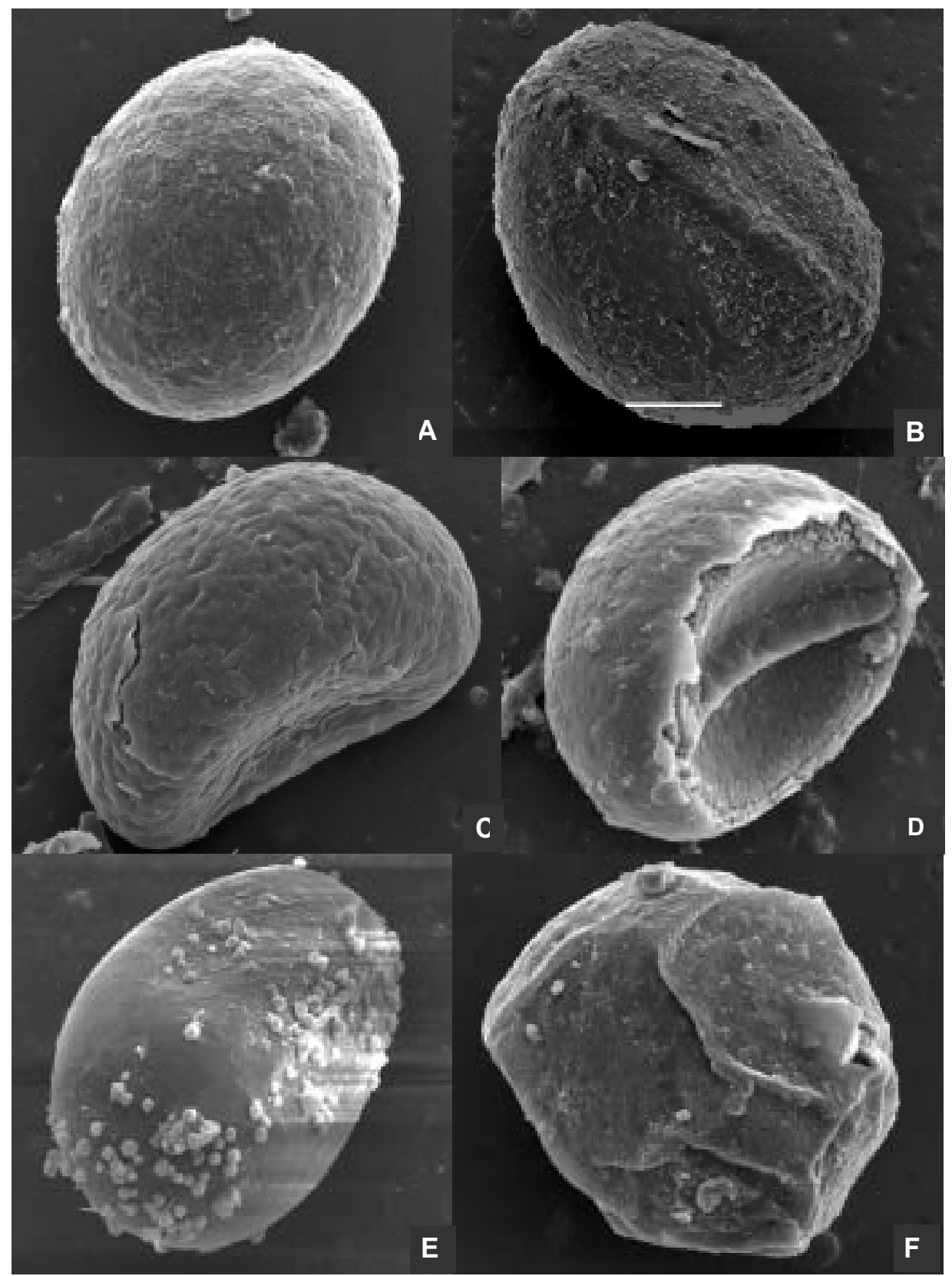

Figura 11. Esporas en especies de Blechnum. A: B. corralense de Corral, Chile, Gunckel 4887 (LP). B: B. stoloniferum de Oaxaca, México, Mickel \& Leonard 4661 (LP). C-D: B. mochaenum subsp. mochaenum de Llanquihue, Chile, Parra 11282 (LP). E: B. fernandezianum de Mas Afuera, Archipiélago de Juan Fernández, Meyer 9594 (LP). E: B. mochaenum subsp. squamipes de Córdoba, Argentina, Castellanos s. n. (LIL 37924). Barra $=10 \mu \mathrm{m}$. 


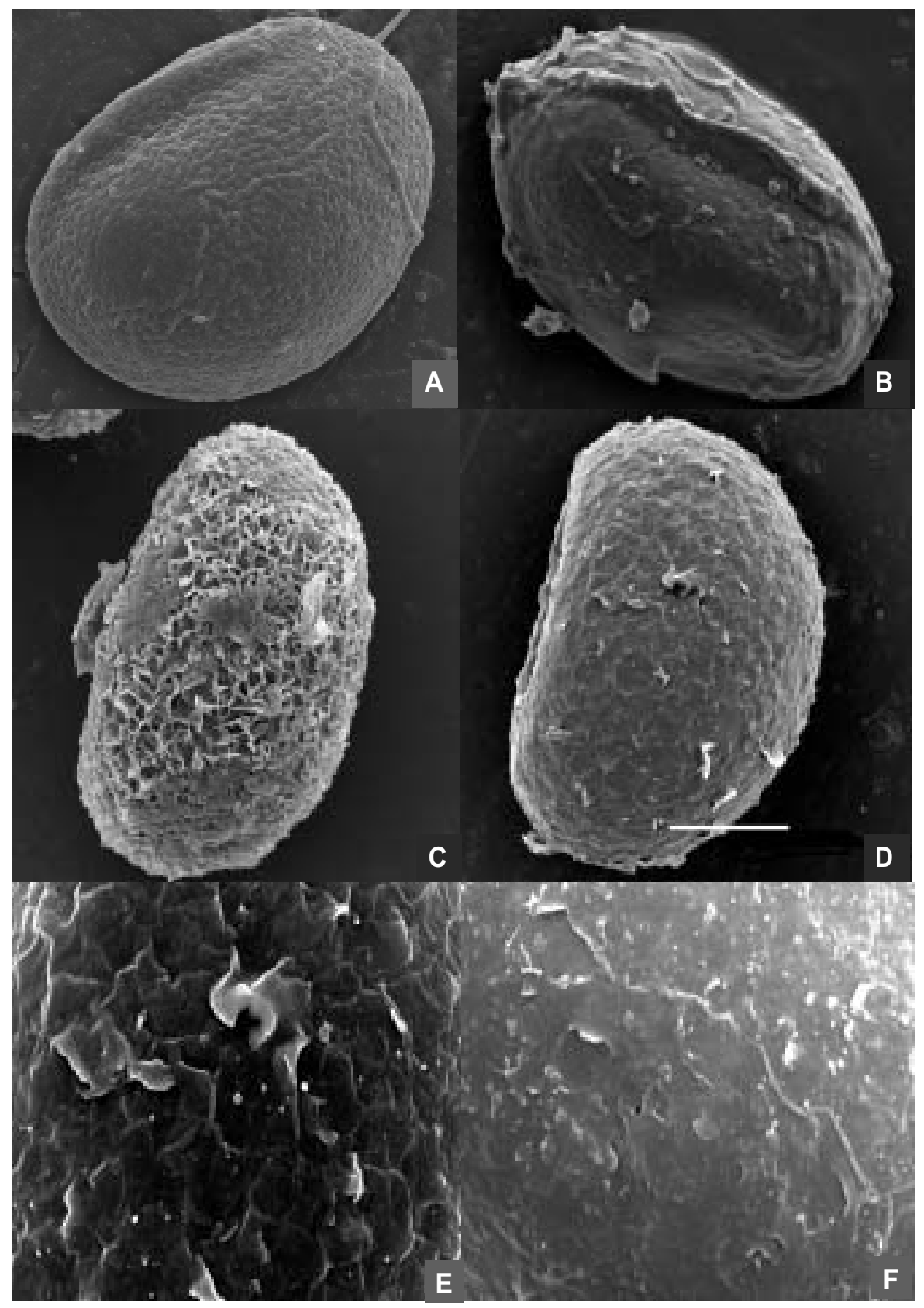

Figura 12 . Esporas en especies de Blechnum. A: B. blechnoides de Concepción, Chile, de la Sota 6024 (LP). B: B. spicant de Enhaut, Suiza, Pedersen 2486 (LP). C y E: B. penna-marina de Tierra del Fuego, Argentina, Torres 1122 (LP). D y F: B. microphyllum de Neuquén, Argentina, Diem 3366 (LP). Barra $=10 \mu \mathrm{m}$ en A-D; $2 \mu \mathrm{m}$ en E-F. 


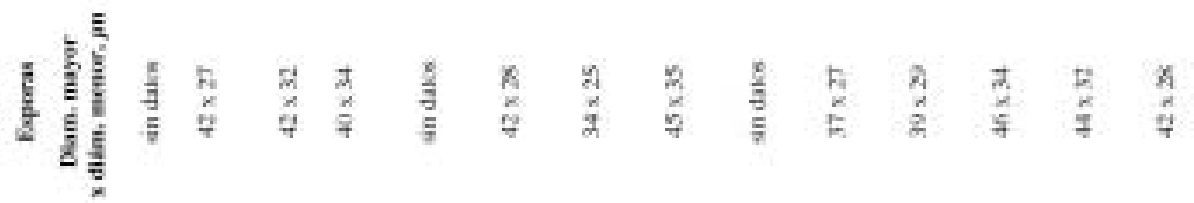

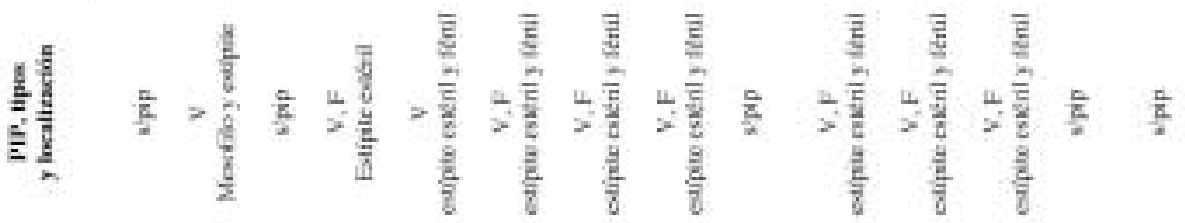

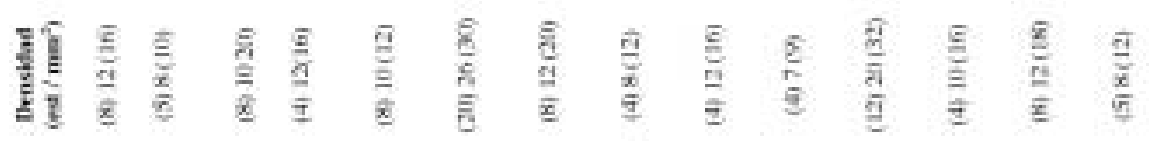

I)

这 \|\|\|\|\|\|\|\|$\|$

$1 H\|\|\|\|\|\|\|\|\|\|$

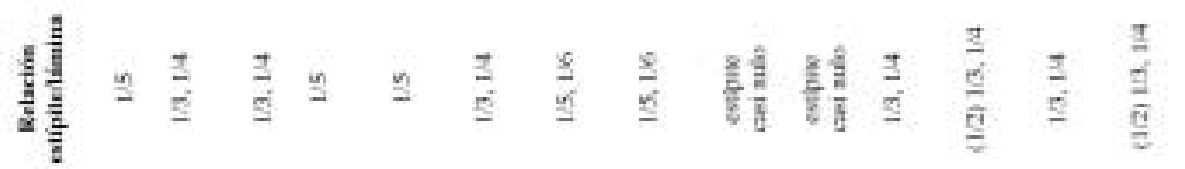

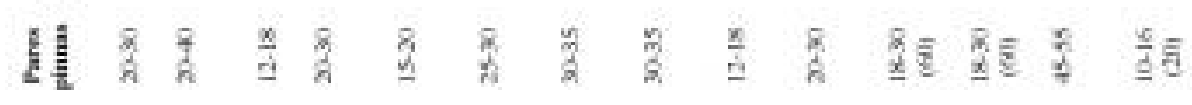

हี

ป⿱艹

궁

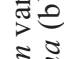

ำ

$\frac{0}{2} \stackrel{2}{2}$

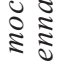

$\infty:$

कृष

즌.

정

$\because \infty$

กั

(2.)

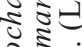

i

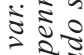

₹ิ

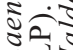

ses

ミลิ

ติำ

ฐี่

ฐัむ

8.05

की

थै

.

क⿺辶

을

능ㄹ

ㅇํㅇ

竞

㐘

n.

घี

吾战

푸요 
tienen paredes uniformemente engrosadas. Pueden ser casi rectas, con modelo epidérmico poligonal, en $B$. spicant (fig. 10 I), con modelo epidérmico subsinoso en ' $B$. mochaenum subsp. mochaenum (fig. $10 \mathrm{~K}$ ), B. fernandezianum y B. microphyllum (fig. 10 L) y sinuoso, con curvas uniformes y profundas en $B$. blechnoides (fig. $10 \mathrm{O}$ ), $B$. mochaenum subsp. squamipes (fig. $10 \mathrm{~N}$ ), $B$. penna-marina (fig. $10 \mathrm{P}$ ) y B. stoloniferum (fig. $10 \mathrm{~J}$ ). El radio celular es 1:1 en las células de los indusios de $B$. stoloniferum y 2-3:1 ó más en los demás taxones.

Las esporas de los taxones estudiados son reniformes o elipsoidales, más raramente, esferoidales, tienen color castaño claro o castaño amarillento y abertura monolete. Las lesuras son largas, se extienden por algo más de dos tercios de la longitud de la cara proximal y a veces prominentes. Son crestadas y más o menos afiladas en esporas de B. spicant; semejan un grueso pliegue, ancho y no crestado, en B. microphyllum y B. penna-marina, mientras que son salientes, con un perfil curvo en los restantes taxones, con excepción de $B$. fernandezianum que tiene una lesura delgada y poco perceptible. Las medidas de las esporas del material estudiado se incluyen en la tabla 1.

El esporodermo está formado por un exosporio psilado y un perisporio con macroornamentación variable. Se encontraron perisporios casi lisos, con superficie externa irregularmente microgranular en $B$. stoloniferum y B. corralense (fig. 11 A-B), con orbículas en B. fernadezianum (fig. 11 E), débilmente rugulados en $B$. mochaenum subsp. mochaenum (fig. 11 C-D), densamente rugulados en $B$. blechnoides (fig. 12 A), con pliegues finos dispuestos irregularmente en B. spicant (fig. 12 B) y con tendencia a formar areolas en $B$. mochaenum subsp. squamipes (fig. $11 \mathrm{~F}$ ). La capa externa del perisporio tiene un aspecto venulado en $B$. microphyllum y $B$. pennamarina (fig. $12 \mathrm{C}-\mathrm{D}$ ). No se vieron las esporas de B. asperum, B. lehmannii y $B$. mochaenum subsp. achalense.

En B. mochaenum subsp. mochaenum se observaron cortes de esporodermo en esporas fracturadas espontáneamente y se distinguieron dos capas: una interna fibrilar a filamentoso-fibrilar, pegada al exosporio, gruesa, de unos $5 \mu \mathrm{m}$ o más y una externa más delgada, densa y compacta, no fibrilar (fig. 11 D). En B. microphyllum y'B. pennamarina no se observaron cortes, pero parece posible interpretar el perisporio como formado por una capa externa muy delgada, que deja ver la más interna, formada por un entrecruzamiento de laminillas muy delgadas de aspecto folioso (Fig 12 E-F).

Hay pocos estudios esporales en relación con este grupo. Lugardon $(1965,1974)$ analizó las esporas de B. spicant mediante microscopios óptico y electrónico de transmisión y de barrido, desde la meiosis a la madurez; Morbelli (1976) ilustró, mediante microscopio óptico, las esporas de $B$. microphyllum, B. mochaenum subsp. mochaenum y B. penna-marina y posteriormente, Tryon \& Lugardon (1990) ilustraron treinta especies procedentes de toda el área de distribución del género, entre ellas las de B. penna-marina, con microscopía electrónica de barrido, aunque no efectuaron correlaciones con los grupos informales.

\section{Clave de los taxones}

1 Láminas con base recta, sin segmentos basales aflébicos .................................... 2

1 Láminas con bases atenuadas, con un número variable de pares de segmentos basales aflébicos

2 Láminas herbáceas, oblongas, venas simples y bifurcadas, segmentos con margen denticulado, escamas del rizoma concolores, ovadas anchas B. microphyllum

2 Láminas coriáceas, lanceolado-lineares; venas bifurcadas una o dos veces, segmentos 
con margen entero o papiloso, escamas del rizoma concolores o discolores, lanceoladas o lineares 3

3 Venas bifurcadas una sola vez, segmentos oblongos con ápice romo y margen papiloso, escamas del rizoma concolores, lanceoladas, con ápice atenuado

B. penna-marina

3 Venas bifurcadas dos veces, segmentos falcados angostos con margen entero, escamas del rizoma discolores, lineares, con márgenes denticulados y un área central esclerificada con aspecto de nervio

B. spicant

4 Segmentos coriáceos .....................................5

4 Segmentos herbáceos o membranáceos......9

5 Margen entero

5 Margen denticulado 6

6 Segmentos triangulares subfalcados con ápice agudo, venas simples, geminadas y bifurcadas, escamas del rizoma lineares, discolores con 'áreas de células esclerificadas, ápices glandulares retorcidos y márgenes denticulados con dentículos retrorsos y engrosados

B. lehmannii

6 Segmentos oblongos o subcirculares con ápice redondeado, venas bifurcadas, escamas del rizoma lanceoladas, concolores, con margen entero, endurecidas en plantas viejas

B. blechnoides

7 Venas simples y bifurcadas, márgenes denticulados hialinos; estípites casi nulos, con escasos pares de segmentos aflébicos que rematan abruptamente la base de la lámina .

Venochaenum subsp. squamipes Venas siempre bifurcadas, una o dos veces, márgenes denticulados rígidos, engrosados; estípites generalmente más desarrollados, con los pares de segmentos aflébicos disminuyendo gradualmente . .8

8 Segmentos triangulares ásperos, erizados, cubiertos por acúleos epidérmicos y pelos setiformes rígidos, venas siempre dos veces bifurcadas B. asperum

8 Segmentos falcados o subfalcados, sin acúleos epidérmicos, venas bifurcadas una o dos veces

B. mochaenum subsp. mochaenum

9 Venas simples solamente ............................. 10

9 Venas simples y bifurcadas .......................... 11

10 Plantas hasta $8-10 \mathrm{~cm}$, estípites pilosopapilosos, amiláceos; escamas del rizoma y base del estípite ovado-lanceoladas con márgenes denticulados

B. corralense

10 Plantas hasta $25 \mathrm{~cm}$, estípites papilosos sin pelos, no amiláceos; escamas del rizoma lanceoladas con márgenes enteros

B. stoloniferum

11 Plantas glabras, segmentos lisos con margen denticulado hialino, venas inmersas, escamas del rizoma deltoides, concolores, estípites papilosos, a veces con 2 haces vasculares solamente

B. mochaenum subsp. achalense

11 Plantas pilosas, segmentos con pilosidad abundante y variada, con margen plano subrepando, venas visibles, escamas del rizoma lanceolado-lineares, discolores, con áreas esclerificadas marginales y distribuidas al azar, estípites papilosos y pilosos, siempre con 3 haces vasculares. B. fernandezianum

\section{Taxonomía y descripción de los taxones}

Blechnum asperum (Klotzsch) J.W. Sturm, Abh. naturhist. Ges. Nürnberg 2: 172. 1858.

Plantas terrestres, hemicriptófitas, de sotobosque, de hasta $40-45 \mathrm{~cm}$ de altura. Rizomas cortamente reptantes a suberectos, casi glabros, estoloníferos. Escamas rizomáticas escasas, lanceoladas angostas, enteras, oscuras y eventualmente endurecidas. Frondas dimórficas, las estériles de 20-35 cm, más largas que las fértiles, éstas con segmentos contraídos y portadoras de cenosoros. Estípites $4-8 \mathrm{~cm}$ de largo en frondas estériles y hasta $10-12 \mathrm{~cm}$ de largo en frondas fértiles, rígidos y firmes, con una zona hipodérmica fibrosa de hasta 15 capas celulares de espesor y tres haces vasculares de tamaño similar. Ejes glabros pero marcadamente aculeado-papilosos. Láminas estériles lanceoladas a lanceoladoelípticas, con ápice agudo y base cuneada, imparipinnadas, pinnado-pinnatífidas; segmentos 20-30 pares, triangulares a subfalcados, anchos en la base, ásperos, de hasta 2-3,5 cm de largo x 1-1,5 cm de ancho, con ápices agudos, superficialmente aculeados y pilosos. Indumento superficial 
abundante, formado por acúleos 1-celulares engrosados agudos y pelos setiformes 1celulares rígidos esclerosados sobre lámina y venas. Venas dos veces bifurcadas, con divisiones en las ramas acroscópica y basiscópica, poco visibles a inmersas, terminadas en grandes hidatodos de contorno elíptico. Láminas fértiles similares en longitud a las estériles pero más reducidas y angostas, con pinnas más cortas y contraídas. Cenosoros mediales, indusio continuo con margen recto. Reproducción vegetativa por yemas terminales situadas en el extremo de estolones portadores de aflebias laterales reducidas, semicirculares.

Distribución geográfica y ecología. Endémica de Chile continental, desde la Isla Mocha(provincia de Arauco) hasta la provincia de Chiloé. Crece en el piso del bosque, en sitios húmedos y frescos; desde el nivel del mar hasta los $500 \mathrm{~m}$. En Valdivia aparece también en bosques regenerados después de incendios (CODEFF, 2002).

Observaciones. Se destaca de otras especies del grupo por sus segmentos ásperos con márgenes denticulados, las venas doblemente bifurcadas y la epidermis cubierta de abundantes acúleos y pelos setiformes rígidos. El esporófito es similar al de $B$. mochaenum, particularmente a las plantas más grandes de B. mochaenum subsp. mochaenum, mientras que el modelo epidérmico está más próximo al de $B$. spicant.

Ejemplares de referencia: CHILE: Arauco: Isla Mocha, camino entre el Faro Oeste La Hacienda, Cordón Central, WeldtRodríguez 1083/378 B (CONC 34359, LP).

Blechnum blechnoides (Bory) Keyserl., Polyp. herb. bunge.: 65. 1873., non Desv. 1827.

Plantas terrestres, halófitas, saxícolas, de suelos salinos y áreas costeras salitrosas. Rizoma erecto a suberecto, formando un breve tronco, escamoso y estolonífero, con estolones desnudos. Escamas rizomáticas lanceoladas grandes, de hasta 9-11 mm, cubriendo densamente el rizoma, raramente caducas, enteras, concolores, frecuentemente oscuras y endurecidas en plantas maduras. Frondas dimorfas erguidas, calatiformes, las fértiles y las estériles iguales en longitud o más largas las primeras, de 10-25 (35) cm de largo. Estípites cortos, de 1-6 (9) cm, basalmente escamosos, con escamas similares a las rizomáticas pero más pequeñas, de 6-8 mm, marcadamente canaliculados en la cara adaxial, con una zona hipodérmica fibrosa de 12-14 capas celulares de espesor, abundante parénquima no amiláceo y tres haces vasculares de tamaño similar. Láminas estériles lanceoladas a linear-lanceoladas, imparipinnadas, pinnatífidas o pinnatisectas, con 18-20 (40) pares de segmentos, con 4-7 pares basales aflébicos, semicirculares; segmentos coriáceos, adaxialmente opacos y abaxialmente brillantes, oblongos a subcirculares, con ápice obtuso, de 6-7 (16) mm largo x 3-5 (11) mm ancho. Indumento superficial ausente. Venas simples y bifurcadas una sola vez, más bien lejos de la costa, inmersas, terminadas en hidatodos grandes de contorno espatulado. Mesofilo y tejidos parenquimáticos de los estipites con protuberancias intercelulares pécticas de tipo verruga. Lámina fértil similar a la estéril, a veces más larga; pinnas fértiles linearlanceoladas o linear-oblongas, muy contraídas, con bases decurrentes. Cenosoros continuos; indusios con margen irregularmente ondulado-dentado y modelo epidérmico sinuoso frecuente con ondas profundas. Esporas elipsoidales, de 42 × 27 $\mu \mathrm{m}$ con perisporio rugulado.

Distribución geográfica y ecología. Chile y Nueva Zelanda. En Chile, desde la provincia de Concepción hasta la de Aisén y en Chiloé, preferentemente en la costa y 
cerca de la orilla del mar hasta $\operatorname{los} 1000 \mathrm{~m}$ de altitud. En Nueva Zelanda, en North Island, South Island, Stewart Island y Campbell Island. Siempre como un elemento costero de suelos salitrosos, en acantilados y grutas costeros, saxícola y aún en agua, sobre rocas mojadas con agua salada.

Observaciones. Rodríguez Ríos (1995) la consideró endémica de Chile, pero Chambers \& Farrant (1996 b) indican que tiene una distribución disyunta. Es una especie adaptada a los suelos salinos costeros y la única del género con estas características. Crece sobre rocas y forma comunidades con otras especies halófilas de acantilados. Posiblemente como una respuesta a estos hábitats, las frondas son suculentas y carnosas. Las medidas promedio de esporas son coincidentes en poblaciones de Chile y de Nueva Zelanda (Chambers \& Farrant, 1996 b; Tabla 1). Chambers (1954) obtuvo un recuento cromosómico de $2 n=66$ para esta especie en material neocelandés. Fenotípicamente es similar a $B$. mochaenum var. mochaenun, aunque sus preferencias ecológicas son muy diferentes y el modelo epidérmico de sus segmentos se aproxima al de B. corralense y B. lehmannii.

Ejemplares de referencia: CHILE: Concepción: Talcahuano, Rocoto, en acantilados, de la Sota 6024 (LP). Talcahuano, Caleta Tumbes, en gruta, Junge 5365 (2 ejemplares LP).

Valdivia: Cordillera Pelada, Escuche 368 (LP). Cordillera Pelada, cerca Huicolla, 50 m, de la Sota 2773 (LP). Corral: La Aguada, en quebrada, Gunckel 2880 (LP). Corral: La Rama, Gunckel 2336 (LP). Mehuín, en playa, "crece en agua, sobre rocas, a la orilla de la playa", Godoy s. $n$. (LP). Llanquihue: Huinay, Parra 11056 (LP).

Blechnum corralense Espinosa, Revista Chilena Hist. Nat. 36: 93. 1932.

Plantas terrestres o saxícolas, pequeñas y delicadas, de no más de 10-12 cm de altura, que crecen cerca de corrientes de agua, humedales o esteros. Rizoma corto, erecto o suberecto, muy delgado, escamoso, con estolones rastreros, epígeos y filiformes. Escamas rizomáticas concolores, rojizas, ovadas a ovado-lanceoladas, con margen distantemente denticulado, con dentículos hialinos unicelulares y ápice retorcidos, a veces escariosas pero no endurecidas. Frondas dimóficas fasciculadas, las estériles 8-10 (12) cm las fértiles 8-12 (14) cm, éstas con estípites más largos que la lámina. Estípites estériles y fértiles filiformes, basalmente escamosos, pilosos y papilosos en toda su longitud y con escamas esparcidas similares a las rizomáticas pero más pequeñas, adaxialmente canaliculados, con un surco profundo, una epidermis papilosa y con pelos uniseriados 2-4 celulares, una zona hipodérmica fibrosa de 2-3 capas celulares de espesor, un parénquima interno reservante, con abundante almidón de granos simples, más o menos ovoides y con tres haces vasculares de tamaño similar. Láminas estériles lanceoladas a oblongo-lanceoladas, imparipinnadas, pinnado-pinnatífidas, con 12-18 pares de segmentos; segmentos membranáceos y delicados, casi translúcidos, oblongos, obtusos y márgenes enteros a algo ondulados o repandos, de unos 1-1,8 cm de largo x 0,3-0,6 cm de ancho. Indumento superficial moderadamente abundante, especialmente en el epifilo y también en el margen, pelos 1-seriados 3-5 celulares, con célula apical cilíndrica muy larga, a veces tan larga como la mitad del pelo. Venas simples, visibles, a veces algo onduladas, terminadas en grandes hidatodos prominentes de contorno elíptico o espatulado. Frondas fértiles linearlanceoladas, generalmente más largas que las estériles, de hasta $10-12 \mathrm{~cm}$, con estípites de hasta 5-7 cm y láminas de hasta 5-6 cm; pinnas fértiles contraídas, distanciadas hasta 
4-6 mm una de otra. Cenosoros casi marginales, con indusio crenado-denticulado y con prolongaciones piliformes pluricelulares. Esporas reniformes, elipsoidales, de $42 \times 32 \mu \mathrm{m}$, con perisporios rugulados con micrornamentación granular muy fina.

Distribución geográfica y ecología. Aunque Rodríguez Ríos (1995) la señala como endémica de Chile, donde se encuentra desde la provincia de Valdivia a la de Chiloé y desde el nivel del mar hasta los $1200 \mathrm{~m}$, en ambientes de bosque húmedo y sombrío, generalmente sobre rocas, también ha sido coleccionada en Yungas, Bolivia, en áreas de selvas nubladas y podría, eventualmente, habitar las selvas del S y SE de Brasil, como otra especie próxima, $B$. andinum, ambas señaladas como especies en peligro de extinción (Amigo et al., 1996; Oliveira Dittrich, 2005).

Observaciones. Tiene stípites flexibles y amiláceos, con almidón muy abundante. Blechnum andinum, no estudiado aquí en detalle, es muy similar a $B$. corralense por el tamaño de las plantas, la textura de los segmentos, las venas simples terminadas en grandes hidatodos y las escamas rizomáticas y peciolares concolores de contorno ovado. Son las dos especies de Blechnum más pequeñas de todas las que se conocen para América en general y podrían ser coespecíficas. Ambas están subcoleccionadas, son raras y sus áreas coinciden parcialmente: $B$. corralense se conoce para Chile y Bolivia y $B$. andinum para Bolivia, S y SE de Brasil (Oliveira Dittrich, 2005) y Perú (León, 1999).

Ejemplares de referencia: CHILE: Valdivia: Corral: Casa Socorros, Gunckel 4887 (LP). Corral San Juan, Gunckel 1961(LIL). Valdivia, "en grutas" sin loc., Gunkel 15615 (LIL).

BOLIVIA: La Paz: Yungas, $2800 \mathrm{~m}$, Alice \& Louis Fay 3005A (MO).
Blechnum fernandezianum (Looser) Prada \& Rolleri stat. nov.

Blechnum blechnoides var. fernandezianum Looser, Revista Univ. (Santiago) 32(2): 61. 1947. (Basiónimo).

Blechnum mochaenum var. fernandezianum (Looser) de la Sota, Bol. Soc. Argent. Bot. 14(3): 196. 1972.

Ind. Loc.: Archipiélago Juan Fernández: Isla Más a Tierra, Camino al Portezuelo, Looser (n. v.).

Plantas terrestres más bien delicadas, gráciles y flexibles. Rizomas erectos o suberectos, escamosos, con abundantes estolones delgados y oscuros, epígeos. Escamas rizomáticas linear-lanceoladas a lanceoladas, discolores, con áreas esclerificadas marginales y distribuidas al azar y ápice reytorcido. Frondas dimórficas, calatiformes, las fértiles más largas que las estériles, 'éstas hasta de $25-30 \mathrm{~cm}$ de largo. Estípites 1/5-1/6 de la longitud total de la fronda, oscuros, con un surco adaxial profundo, con epidermis papilosa y pilosa, con una zona hipodérmica fibrosa de 8-10 capas celulares de espesor y tejido parenquimático no amiláceo con tres haces vasculares de tamaño similar o con el haz mediano algo más más pequeño. Láminas estériles linear-lanceoladas a lanceoladas, imparipinnadas, pinnatisectas, con 20-30 pares de segmentos próximos y hasta 10-12 pares basales aflébicos, de contorno subcircular; segmentos triangulares algo incurvados, de 1-2 cm de largo x 0,5-0,8 cm de ancho, membranáceos y translúcidos, con ápices romos y enteros, ondulados, con células marginales hialinas. Indumento superficial abundante y variado: pelos 1seriados 3-10 celulares, capitados y no capitados y pelos setiformes fláccidos, 1-3 celulares, todos sobre láminas, venas, costas y ejes en general. Venas simples y bifurcadas, muy visibles, terminadas en grandes hidatodos sobresalientes de contorno 
elíptico. Láminas fértiles hasta 30-35 cm de largo, con 20-30 pares de pinnas muy contraídas, falcadas a arqueadas, angostas y distanciadas, con ápices mucronados estériles. Cenosoros submarginales continuos; indusios con márgenes irregularmente erosos y modelo epidérmico subsinuoso. Esporas elipsoidales, de 40 x 34 $\mu \mathrm{m}$, con perisporio psilado, orbículas rugosas y lesura delgada poco perceptible.

Distribución geográfica y ecología. Endémica del archipiélago de Juan Fernández. En sitios muy húmedos.

Observaciones. Se ha considerado apropiado cambiar el estatus de este taxón. Difiere notablemente de $B$. mochaenum y sus subespecies por las láminas linearlanceoladas angostas, flexibles y delicadas, los segmentos membranáceos abundantemente pilosos en epifilos, hipofilos y márgenes, los márgenes subrepandos hialinos no denticulados, las venas bifurcadas delgadas y muy visibles, los estípites pilosos además de papilosos, las células epidérmicas con paredes muy delgadas, las esporas psiladas con orbículas verrucosas y su carácter de endemismo insular.

Ejemplares de referencia: CHILE: Juan Fernández: Más Afuera, Quebrada de la Mata Maqui, on trail to Correspondencia Camp, Meyer 9437 y 9745 (LP, US). End of Casas Canyon, Solbrig et al. 3694 (LP, US). Masatierra, Pangal, abundant in Maqui forest, Solbrig et al. 3822

(GH, LP, US). sin coll. (CONC 52503, MA). Pangal Falls, Meyer 9594 (LP). Subida al Mirador de Selkirk, desde San Juan Bautista, Agua del Guindal, $260 \mathrm{~m}$, Marticorena et al. 9002 (MA).

Blechnum lehmannii Hieron. Bot. Jahrb. Syst. 34: 473. 1904.

Plantas terrestres, de selvas prístinas o poco perturbadas. Rizomas largamente ascendentes, escamosos, sin estolones o con estolones escasos. Escamas rizomáticas linear-lanceoladas, denticuladas con dentículos engrosados retrorsos, con áreas esclerosadas marginales y distribuidas al azar o a veces totalmente oscurecidas. Frondas dimorfas, las fértiles casi tan largas como las estériles, de 20-35 cm de largo. Estípites escamosos en la base, con escamas similares a las rizomáticas pero más pequeñas y no oscurecidas, adaxialmente cóncavos, con epidermis estriada y engrosada, una zona hipodérmica fibrosa de 12-14 capas celulares de espesor, parénquima abundantemente amiláceo y tres haces vasculares de tamaño similar. Láminas estériles elípticas pinnatisectas, gradualmente reducidas hacia el ápice y la base, en ésta con 4-5 pares aflébicos de contorno semicircular; 15-20 pares de segmentos; segmetos estériles triangulares a subdeltoides, algo falcados, con margen entero y ápice subagudo, coriáceos, de 2-3 cm de largo x 1,2-1,8 cm de ancho. Indumento superficial ausente. Venas simples, bifurcadas y geminadas, poco visibles, terminadas en grandes hidatodos de contorno elíptico. Láminas fértiles oblanceoladas o lanceoladas; pinnas fértiles lineares, muy contraídas, casi sin tejido estéril, 12-17 pares. Cenosoros continuos; indusio con margen eroso irregular.

Distribución geográfica y ecología. Se distribuye desde el $S$ de México y Centroamérica y desde Colombia hasta Bolivia y Brasil en Sudamérica. Desde el nivel del mar hasta los $3000 \mathrm{~m}$. Crece en selvas prístinas o poco perturbadas, bajas, montanas y pedemontanas pero es muy tolerante a menores niveles de humedad, y puede crecer en barrancos y paredes rocosas, y en bordes de selvas o bosques, cerca de cursos de agua.

Observaciones. Stolze (1981) lo cita 
para Guatemala y lo considera intermedio entre $B$. divergens y $B$. lherminieri. Mickel \& Beitel (1988), Tryon \& Stolze (1993) y Moran (1995) lo consideran coespecífico con $B$. lherminieri. Lellinger (2003) lo trata como una subespecie de $B$. lherminieri, distinguiéndola de la subespecie tipo por las láminas estériles gradualmente angostadas hacia la base, un carácter que se encuentra en varias especies del grupo B. pennamarina. Mickel \& Smith (2004) mencionan la existencia de esporas de diferentes tamaños en los materiales de B. lehmannii y/o $B$. lherminieri y las mantienen como especies distintas. Oliveira Dittrich (2005) la segrega del grupo $B$. lineatum y la ubica en el grupo $B$. divergens, junto con $B$. organense y B. sampaioanum. Kasmirczak (1999) señala que es relativamente rara en Brasil, que estaría en peligro de desaparición por la tala creciente del hábitat original y reporta un híbrido estéril entre $B$. lehmannii y $B$. divergens. Blechnum lehmannii es muy semejante a $B$. mochaenum y podrían tratarse como subespecies, pero quedan dudas en relación con la presencia o ausencia de estolones y con las esporas de B. lehmannii, de las que no se conoce la morfología, por lo que se las mantiene como especies diferentes, aunque las semejanzas entre ambas son notables y las plantas adultas de ambos taxones se confunden fácilmente; las escamas rizomáticas son muy similares salvo por los dentículos marginales y también se asemejan los modelos epidérmicos. Se distinguen, entre otros rasgos, por la venación, el indumento superficial, el margen entero o denticulado y algunas variaciones en el modelo epidérmico y el tamaño estomático. Smith \& Mickel (1977) registran para $B$. lehmannii $2 \mathrm{n}=396$, es decir, sería un dodecaploide basado en $\mathrm{x}=33$, analizado en material de Honduras.

Ejemplares de referencia: BOLIVIA: La Paz: Murillo, valle del Río Zongo, 23,8 $\mathrm{km}$ al N de la cumbre, $2900 \mathrm{~m}$, Solomon 16392 (LP, MO). BRASIL: Minas Geraes: Distrito Carangola, trail Areponga to Fazenda de Grana, 970 m, Mexia 4237 (US. isótipo de $B$. mexiae). COLOMBIA: Chocó: Municipio de San José del Palmar, cerro al SO de la población, $1300 \mathrm{~m}$, Forero et al. 3407 (MA). COSTA RICA: Alajuela: slope of Volcán Poás, at bridge just below Hacienda El Tirol, Mickel 2472 (LP).

Blechnum microphyllum (Goldm.) C.V. Morton, Amer. Fern J. 60: 103. 1970.

Plantas terrestres, de bosques hiperhúmedos, más bien pequeñas y delicadas, termófilas. Rizoma suberecto, escamoso, con estolones delgados, casi filiformes, oscuros o castaño-amarillentos. Escamas rizomáticas concolores, ovadas anchas y auriculadas. Frondas dimórficas, de hasta 20-22 cm, las estériles siempre más cortas que las fértiles. Estípites flexibles, adaxialmente cóncavos, los estériles aproximadamente $1 / 3$ de la longitud total de la fronda y los fértiles tan largos como las láminas, con epidermis papilosa, con una zona hipodérmica fibrosa de 3-4 capas celulares de espesor, abundante parénquima no amiláceo y tres haces vasculares de tamaño similar. Láminas estériles lanceoladas, con ápice atenuado o agudo y base abruptamente recta, imparipinnadas, pinnado-pinnatífidas, con 25-30 pares de segmentos; segmentos próximos a imbricados, oblongos, con ápice agudo, margen denticulado y textura herbácea delicada o algo subcoriácea en plantas de sitios más expuestos, hasta de 14-15 mm de largo x 3-5 mm de ancho. Indumento superficial moderadamente abundante, especialmente en epifilo, pelos 1-seriados 36 celulares, más o menos capitados. Venas simples y bifurcadas terminadas en grandes hidatodos de contorno elíptico. Láminas 
fértiles oblongas, angostas, con 30-35 pares de pinnas lineares distanciadas, de hasta 1 cm de largo y muy contraídas. Cenosoros continuos; indusios con margen erosodentado, irregular y modelos epidérmicos subsinuosos. Esporas reniformes, elipsoidales, de $42 \times 28 \mu \mathrm{m}$, con perisporios externamente de aspecto venulado, con una capa interna folioso-alveolar.

Distribución geográfica y ecología. Chile y Argentina. En Chile, desde Valparaíso hasta la región del Bío-Bío, desde la provincia de Cordillera hasta la de Llanquihue. 0-2600 $\mathrm{m}$ de altitud. En Argentina exclusivamente en Neuquén y Río Negro, en la región del lago Nahuel Huapi. En bosques hiperhúmedos, áreas termales, zonas rocosas en bosques de pinos y margen de corrientes de agua, bajo Araucaria; ocasionalmente, en microambientes, en lugares más secos y expuestos, desde 800 a más de $2000 \mathrm{~m}$.

Observaciones. Rodríguez Ríos (1995) consideró a' $B$. microphyllum una especie bien caracterizada mientras que Chambers \& Farrant (1996 a) la tratan como una subespecie de B. penna-marina. Blechnum microphyllum se distingue de $B$. pennamarina por varios caracteres, como los contornos y ápices de las pinnas, los márgenes denticulados, la textura herbácea, el indumento relativamente abundante, el patrón de venación, el modelo epidérmico, la densidad y las dimensiones estomáticas y las distintas preferencias ecológicas: mientras B. penna-marina suele crecer tanto en lugares húmedos como en lugares abiertos o expuestos y es común en suelos ácidos, mallines y márgenes de turberas, $B$. microphyllum se encuentra en bosques hiperhúmedos, a la orilla de lagos y corrientes (Argentina) y también en la cercanía de zonas termales (bosques andinopatagónicos de Argentina y Chile).

$$
\text { Ejemplares de referencia: }
$$

ARGENTINA : Neuquén: Kurtz, F. 6249 (CORD). Río Agrio, Lago Caviahué, 1700 m, Diem 3366 (LP). Cavihué, Kuhnemann 24 (LP). Copahue, Cabrera et al. 22898 (LP) y Monticelli $s / n$ (LP). Aluminé: Ruta provincial 11, $23 \mathrm{~km} \mathrm{~N}$ del Lago 'Ñorquinco, hacia Paso Icalum, Correa et al. 10069 (LP). Parque Nacional Lanín, Mirador del Pil-Pil, paso Córdoba, camino a Siete lagos y paso Códoba, cascada sobre ruta 234, Prada $s / n$ (LP, MA). Río Hermoso, Prada $s / n$ (LP, MA). CHILE: Bío-Bío: Laguna de Las Lajas, Faldas de Sierra Velluda, Ricardi \& Marticorena 26218 (CONC, LP). Maule: 800-1500 m, 35.51 S 71.06 W, Arroyo, M. T. K. et al. 20114 (CONC; SGO). Nuble: Termas de Chillán, región del Bío-Bío, Pedersen 14240 (LP).

Blechnum mochaenum G. Kunkel, Nova Hedwigia 13: 340. 1967.

De las cuatro variedades establecidas por de la Sota (1972 b), aquí se reconocen solamente tres, elevadas a la categoría de subespecie:

\section{a.- Blechnum mochaenum subsp. mochaenum}

Plantas terrestres. Rizomas erectos o suberectos, escamosos, con estolones gruesos, reptantes epígeos y lisos, no escamosos. Escamas rizomáticas lanceoladodeltoides, discolores, con áreas esclerificadas distribuidas al azar, grandes, hasta de 7-9 mm de largo, enteras. Frondas dimórficas, calatiformes, las fértiles más largas que las estériles, 'éstas hasta de 30-40 cm de largo en las plantas más robustas. Estípites muy cortos, 1/5-1/6 de la longitud total de la fronda, oscuros, adaxialmente cóncavos, algo rígidos, con epidermis papilosa, una zona hipodérmica fibrosa de más de 15 capas celulares de espesor y abundante almidón de granos simples, tanto en el tejido parenquimático como en las capas internas 
parcialmente esclerosadas de la zona fibrosa, con tres haces vasculares de tamaño similar. Láminas estériles lanceoladas a lanceoladoelípticas, imparipinnadas, pinnatisectas, con 30-35 pares de segmentos próximos a distanciados, nunca imbricados, con 7-10 pares basales aflébicos, de contorno subcircular; segmentos falcados o subfalcados, subcoriáceos a coriáceos, con ápices agudos y márgenes denticulados formados por dentículos rígidos acroscópicamente dirigidos, de 15-20 mm de largo x 4-6 mm de ancho. Indumento superficial moderadamente abundante, pelos 1-seriados 3-10 celulares, capitados y no capitados y pelos setiformes unicelulares fláccidos. Venas simples y bifurcadas; en algunos ejemplares grandes, venas dos veces bifurcadas con la división en la rama acroscópica, siempre poco visibles, terminadas en grandes hidatodos de contorno elíptico o subespatulado. Láminas fértiles con 25-30 pares de pinnas contraídas, falcadas a arqueadas, ascendentes, angostas y distanciadas, con bases decurrentes sobre el raquis. Cenosoros continuos; indusios submarginales con márgenes irregularmente erosos y modelo epidérmico subsinuoso. Esporas elipsoidales, de 34 × $25 \mu \mathrm{m}$, con perisporio rugulado; ocasionalmente, ejemplares con esporas más grandes, uniformes y elipsoidales, de 45 x $35 \mu \mathrm{m}$, también con células epidérmicas y estomas de tamaño mayor que en los especímenes con esporas más pequeñas.

Distribución geográfica y ecología. Crece en Chile y sur de Argentina (Neuquén, Río Negro), en bosques hiperhúmedos $\mathrm{y}$ áreas protegidas, próxima a cursos de agua. Hasta los $1800 \mathrm{~m}$ de altitud.
Ejemplares de
referencia:

ARGENTINA: Neuquén: margen oriental del Lago Queñi, 820 m, Gentili 814 (LP). Isla Victoria, Diem 1192 (LP).

Cascada de Chochín, senda a Chochín, desvío del camino a Hua-hum, Prada s/n (LP, MA). Camino a Paimún, Prada $s / n$ (LP, MA). Lago Nahuel Huapi, Brazo Blest, Puerto Blest, camino a la cascada de los Cántaros, Prada $s / n$ (LP, MA). Chubut: Futaleufú: Parque Nacional Los Alerces, Lago Cisnes, Roig et al. 13907 (LP). Río Negro: Laguna Frías, Conte 16 (LP). 'CHILE: Arauco: Isla de Mocha: camino entre el Faro Oeste y La Hacienda, Cordón Central, Weldt-Rodríguez 1111/406 (CONC 34368, LP).Concepción: Coronel Santa Juana: Duralí, Rodríguez Ríos 2 (CONC 33807, LP). Talcahuano: Caleta Tumbes, de la Sota 6015 (LP). Llanquihue: Lago Puelo, Parra 11282 (LP). PEULLA, Pfister 13554 (LP). Malleco: Parque Nacional Contulmo, de la Sota 6009 (LP).

Osorno: Parque Nacional Puyehué, Roig 13662 (LP) y Roig et al. 13659 (LP). Aguas Calientes, Debandi 9 (LP). IX REGIÓN: Cunco, Lago Colicó, Debandi 51 (LP).

\section{b.- Blechnum mochaenum subsp. achalense}

(Hieron.) Prada \& Rolleri stat. nov.

Blechnum lanceolatum var. achalense Hieron., Bot. Jahrb. Syst. 22: 381. 1896. (Basiónimo).

Blechnum blechnoides var. achalense (Hieron.) Looser, Revista Univ. (Santiago) 32(2): 62.1947.

Blechnum mochaenum var. achalense (Hieron.) de la Sota, Bol. Soc. Argent. Bot. 14(3): 196. 1972.

Plantas terrestres pequeñas. Rizomas erectos o suberectos, escamosos, con estolones muy delgados y desnudos. Escamas rizomáticas triangulares a deltoides, concolores, con base ancha y ápice retorcido. Frondas dimórficas, calatiformes, las fértiles más largas que las estériles, 'éstas de no más de 20-25 cm de largo. Estípites ausentes o muy cortos, delicados, de color amarillo pajizo, flexibles, con un surco profundo, papilosos, con una zona hipodérmica fibrosa 
de 4-5 capas celulares de espesor y tejido parenquimático sin almidón; 2 (3) haces vasculares, el central más pequeño o ausente. Láminas estériles lanceoladas a lanceoladoelípticas, imparipinnadas, pinnatisectas, con 12-18 pares de segmentos próximos, 4-5 pares basales aflébicos, de contorno subcircular o tan reducidos que la base cesa abruptamente; segmentos oblongos, con ápices romos y márgenes onduladorepandos, membranáceos a herbáceos, delicados, de 1-1,5 cm de largo x 0,5-0,8 cm de ancho. Indumento superficial escaso o ausente. Venas simples y bifurcadas, poco visibles; en algunos ejemplares, venas simples solamente, siempre terminadas en grandes hidatodos de contorno elíptico o subcircular. Láminas fértiles hasta $20 \mathrm{~cm}$ de largo, con 18-22 pares de pinnas contraídas, falcadas a arqueadas, ascendentes, muy angostas y distanciadas, con bases decurrentes sobre el raquis. Cenosoros continuos; indusio submarginal con márgenes uniformemente ondulados y modelo epidérmico sinuoso frecuente.

Distribución geográfica y ecología. Noroeste de Argentina (Salta), Sierras Pampeanas (Córdoba) y bosques andinopatagónicos (Neuquén, Río Negro, Chubut). Observaciones. De la Sota (1972 b) correlaciona las variedades con la geografía y duda de la indicación de Looser (1947) para la Patagonia Argentina. Durán (1997) menciona ejemplares de Córdoba y también la cita para los bosques andino-patagónicos de Neuquén, Río Negro y Chubut. Aquí se ha visto material del NO (Salta), escaso y con frondas fértiles ausentes o inmaduras. En las planchas de herbario se encuentra material de esta subespecie mezclado con $B$. mochaenum subsp. squamipes; las plantas difieren por el modelo epidérmico y los contornos de los segmentos. El material de B. mochaenum subsp. achalense analizado podría ser inmaduro y eventualmente, podría tratarse de una planta juvenil de $B$. mochaenum subsp. squamipes ya que procedía de las mismas colecciones y localidades. La escasez de material no ha permitido comprobar esta hipótesis a través de la ontogenia de la epidermis y al no haber podido estudiar las esporas, hemos preferido, por el momento, considerarla como una subespecie diferente.

Ejemplares de referencia: ARGENTINA: Salta: Santa Victoria, Los Toldos, Finca El

Nogalar, Río Huaico, 1800 m (saxícola, en área aterrazada, sobre musgos), Cassá et. al. 255 (LP)-planta de la izquierda- y Cassá et al. 235 (LP).

c.-Blechnum mochaenum subsp. squamipes (Hieron. ) Prada \& Rolleri stat. nov.

Blechnum lanceolatum var. squamipes Hieron., Bot. Jahrb. Syst. 22: 381. 1896. (Basiónimo).

Blechnum mochaenum var. squamipes (Hieron.) de la Sota, Bol. Soc. Argent. Bot. 14: 196. 1972.

Plantas terrestres. Rizomas erectos o suberectos, escamosos, con estolones gruesos y desnudos o con escamas muy pequeñas. Escamas rizomáticas lanceoladas, largamente atenuadas, a veces con ápices retorcidos, concolores, castañas, claras. Frondas dimórficas, aglomeradas, calatiformes, las fértiles más largas que las estériles, 'éstas hasta de 25-30 cm de largo en las plantas más robustas. Estípites breves, oscuros, con un surco adaxial profundo, rígidos, con epidermis papilosa, una zona hipodérmica fibrosa de unas 12 capas celulares de espesor cuyas células contienen abundante almidón de granos simples, tanto en el tejido parenquimático como en las capas internas parcialmente esclerosadas de la zona fibrosa, con tres haces vasculares de tamaño similar. Láminas estériles 
lanceoladas a lanceolado-elípticas, con base cuneada a atenuada, imparipinnadas, pinnatífidas, con 20-30 pares de pinnas contiguas y un número variable de pares basales aflébicos, de contorno subcircular; segmentos triangulares algo curvados acroscópicamente pero no falcados, de 1-1,8 $\mathrm{cm}$ de largo x 0,3-0,5 cm de ancho, subcoriáceos a coriáceos, con ápices agudos y márgenes denticulados formados por dentículos rígidos acroscópicamente dirigidos, con venación poco visible. Indumento superficial ausente o muy escaso, sólo con pelos 1-seriados 3-5 celulares, esparcidos. Venas simples y bifurcadas, a veces las simples predominantes, terminadas en grandes hidatodos sobresalientes de contorno elíptico. Láminas fértiles con 2030 pares de pinnas muy contraídas, falcadas a arqueadas, angostas y distanciadas, a veces muy largas, de hasta 20-25 mm, con ápices mucronados estériles. Cenosoros continuos, submarginales; indusios con márgenes irregularmente erosos y modelo epidérmico sinuoso. Esporas elipsoidales, de $37 \times 27 \mu \mathrm{m}$, con perisporio con pliegues finos con tendencia a formar areolas.

Distribución geográfica y ecología. Argentina y S-SE de Brasil. Crece en áreas serranas, en microambientes húmedos de las Sierras Pampeanas del centro de Argentina (Córdoba) y Sierras del NO (Jujuy, Catamarca y Tucumán). Kasmirczak (1999) y Oliveira Dittrich (2005) lo citan para S y SE de Brasil, siempre en lugares húmedos y a mediana altura, entre 1200 y $1800 \mathrm{~m}$.

Observaciones. Oliveira Dittrich (2005) la incluye también en el grupo $B$. pennamarina y la considera afín con $B$. lehmannii. Tanto B. mochaneum subsp. mochaenum como B. mochaneum subsp. squamipes son muy semejantes entre sí y con $B$. lehmannii (ver comentarios bajo esa especie).

$$
\text { Ejemplares de referencia: }
$$

ARGENTINA: Catamarca: Andalgalá,
Esquina Grande, Joergensen 1571 (LP, LIL, US). Córdoba: Sierra Grande: Cuesta del Mogote, Castellanos s. n. (LIL 37924). Jujuy: El Cucho, Cerro labrado, Potrero de las Mulas, de la Sota 4373 (LP, US). Salta: Santa Victoria, Los Toldos, Finca El Nogalar, Río Huaico, 1800 m (saxícola, en área aterrazada, sobre musgos), Cassá et. al. 255 (LP)-planta de la derecha-. Tucumán: Quebrada Pueblo Viejo, de la Sota 4070 (LP). Estancia Las Pavas, Puesto El Saladillo, Venturi 3001 (LIL).

Blechnum penna-marina (Poir.) Kuhn, Filic. afr. 92. 1868.

Plantas terrestres o saxícolas, de turberas, estepas graminosas, bosques húmedos o abiertos y áreas expuestas, pequeñas a medianas. Rizoma cortamente reptante a suberecto, escamoso, frecuentemente con raíces micorrícicas y estolones delgados, casi glabros. Escamas rizomáticas lanceoladas a lanceoladodeltoides, algo auriculadas, concolores, con margen entero o muy distantemente denticulado. Frondas dimóficas, las fértiles notoriamente más largas que las estériles, 'éstas de 8-70 cm de largo. Estípites flexibles, adaxialmente cóncavos, carnosos, de hasta $30 \mathrm{~cm}$ de largo, los estériles aproximadamente $1 / 3$ de la longitud total de la fronda y los fértiles tan largos como las láminas o más, basalmente escamosos, con escamas similares a las rizomáticas pero más pequeñas y caducas, con epidermis papilosa, una zona hipodérmica fibrosa de 3-4 capas celulares de espesor, abundante parénquima no amiláceo y tres haces vasculares de tamaño similar. Lámina estéril lanceolada angosta, imparipinnada, pinnado-pinnatífida; segmentos contiguos, hasta 60 pares, obtusos, a veces submucronados, con margen papiloso, de 0,6-1,8 cm de largo x 0,4-0,8 $\mathrm{cm}$ de ancho. Indumento superficial 
moderadamente abundante, especialmente en epifilo, pelos 1-seriados 3-6 celulares, más o menos capitados. Venas bifurcadas predominantes, inmersas, terminadas en grandes hidatodos de contorno elíptico. Lámina fértil oblonga angosta, pinnas lineares falcadas, distanciadas unos $3 \mathrm{~mm}$. Cenosoros submarginales; indusio profundamente inciso a fimbriado, con prolongaciones piliformes y modelo epidérmico sinuoso con curvas profundas y frecuentes. Esporas reniformes, elipsoidales, de 39 × $29 \mu \mathrm{m}$, con perisporio externamente rugulado y con una capa interna foliosolaminar; ocasionalmente, ejemplares con esporas más grandes, también elipsoidales, de 46 × $34 \mu \mathrm{m}$, y en éstos también células epidérmicas y estomas de tamaño mayor que en los especímenes con esporas más pequeñas.

Distribución geográfica y ecología. Ampliamente distribuida en el hemisferio austral: Australia, Tasmania, Nueva Zelanda, Sudáfrica, islas del Atlántico, 'Índico y Pacífico austral. Mickel \& Smith (2004) la citan para México y Mesoamérica (Guatemala). En Sudamérica crece en Perú, hasta los $3600 \mathrm{~m}$, en las selvas húmedas de Carabaya, Puno (León, 1999), Bolivia, hasta los $4500 \mathrm{~m}$ en los Andes, Brasil y Chile, desde la provincia de Malleco hasta la provincia Antártica Chilena. En la Argentina se encuentra en el NO, en el bosque montano de aliso y pastizales de altura, entre los 2000 y 3600 m, Sierras Pampeanas del centro, Sierras Australes de Buenos Aires, bosques andino-patagónicos, desde Neuquén hasta Tierra del Fuego e Islas Malvinas.

Observaciones. De la Sota (1970 a) consideró a $B$. penna-marina una especie algo variable cuyas variaciones no avalarían categorías infraspecíficas. Chambers \& Farrant (1996 a) segregaron cuatro subespecies sobre la base del tamaño de las plantas y el margen de los segmentos ( $B$. penna-marina subsp. alpina, B. pennamarina subsp. boliviana, $B$. penna-marina subsp. microphylla y B. penna-marina subsp. penna-marina). El material de Perú fue determinado por León (1999) como $B$. penna-marina subsp. boliviana. Los estudios aquí realizados sobre material de Argentina, Bolivia, Brasil y Chile, en plantas de diferentes tamaños, algunas coexistiendo en el mismo ambiente, sugieren que las categorías infraespecíficas son innecesarias. Es posible que la plasticidad de la especie se relacione también con su capacidad de adaptación a ambientes fríos (Bannister \& Fagan, 1989) y sustratos con diferentes grados de humedad, en este caso por asociaciones micorrícicas endotróficas que son frecuentes en las raíces (Fernández et al.; 2005). Aunque se trata de especies afines, B. penna-marina y B. microphyllum difieren en el contorno, margen, imbricación, textura y caracteres epidérmicos de los segmentos, ecología y distribución geográfica, rasgos suficientes para no tratarlas como coespecíficas. Brownlie (1954) encontró dos números cromosómicos en $B$. penna-marina: $2 n=66$ y $2 n=68$ en material de Nueva Zelanda y Jara-Seguel (2006) reporta $2 n=66$ en el material chileno. En tres ejemplares de Argentina, uno de Neuquén, Gómez Rozas 503 (LP) y dos de Tierra del Fuego, Torres 1122 (LP) y Maldonado s. n. (LP), se encontraron esporas, células epidérmicas y estomas de tamaños mayores que en el resto de los materiales estudiados, por lo que es posible que existan diferentes niveles de ploidía que, sin embargo, no se reflejan en la morfología externa de las plantas. En la Patagonia argentina y en Chile es una especie muy abundante en comparación con otras del género. Blechnum turbioense Frenguelli, un fósil descrito sobre la base de improntas de frondas estériles y fértiles procedente del Eoceno superior (Terciario) del valle del Río Turbio (Santa Cruz, Argentina), de una 
antigüedad de unos 40 millones de años, podría asignarse a $B$. penna-marina (de la Sota, 1970 a).

Ejemplares de referencia: ARGENTINA: Chubut: Krapovickas, $A$. 4029 (LP). Chubut: Koslowsky, J., s.n. (LP19116). Córdoba: Minas: Sierras Grandes, 'Gautier s/n. (LP). Jujuy: $2250 \mathrm{~m}$, de la Sota, E. R. 2895 (LP). Neuquén: Huiliches: Baños de Lahuén-Có, Gómez \& Rosas 503 (LP). Río Negro: Río Manso, al pie del Tronador, cascada Nacimiento, 110 m, Diem 3087 (LP). Tierra del Fuego: Puerto Cook, Torres 1122 (LP). Estancia Moat, 1903-05, ruta provincial J, $105 \mathrm{M}$, Rodríguez et al. s. n. (LP, MA). Estancia Marina, 1203-05, 240 m, Rodríguez et al. s. n. (LP, MA). BOLIVIA: La Paz: Larecaja, salida de Sorata en dirección a Consata, $3450 \mathrm{~m}$, Fernández Casas \& Molero 6582 (MA). BRASIL: Santa Catarina: Lages, Spannagel s. n. (LIL 474029). CHILE: X Región: Provincia Palena, 10,4 km SE of Puerto Ramírez on road to Palena, Stuessey et al. 7181 (MA). XII Región: Provincia Tierra del Fuego, Sector Río Cóndor, Forestal Trillium, Pisano et al. 7910 (MA).

Blechnum spicant (L.) Sm., Mem. Acad. Roy. Sci. (Turin) 5: 411. 1793.

Plantas terrestres o saxícolas, generalmente de suelos ácidos, turbosos o neutros. Rizomas cortamente rastreros, ascendentes o erectos, escamosos, con estolones delgados y oscuros. Escamas rizomáticas linear-lanceoladas, con márgenes denticulados o eroso-denticulados, discolores, con un área central esclerosada que va desde la base hasta el ápice algo retorcido y oscuro, de 5-10 $\mathrm{mm}$ de largo. Frondas dimórficas, las estériles totalmente divaricadas a esparcidas, tocando distalmente el sustrato, formando una roseta, de $20-70 \mathrm{~cm}$ de largo y las fértiles erguidas y más largas que las estériles. Estípites más bien rígidos, cóncavos o levemente canaliculados, papilosos y pilosos, los estériles hasta $1 / 3$ de la longitud total de la fronda y los fértiles casi tan largos como las láminas, con una zona hipodérmica fibrosa de 12-14 capas celulares de espesor, abundante parénquima no amiláceo y tres haces vasculares de tamaño similar, basalmente escamosos, con escamas similares a las rizomáticas pero más pequeñas. Ejes glabros. Láminas estériles lanceoladas, imparipinnadas, pinnadopinnatífidas, con ápice agudo y base recta sin aflebias; segmentos falcados angostos, 45-55 pares, subcoriáceos, brillantes, con margen liso y ápice agudo, glabros o muy escasamente pilosos, con pelos 1-seriados 26 celulares, algo capitados. Venas doblemente bifurcadas, con la segunda ramificación en la rama acroscópica. Láminas fértiles linear lanceoladas, más largas que las estériles y con segmentos muy contraídos. Cenosoros muy cerca de la vena media; indusios continuos con margen recto o levemente irregular y modelos epidérmicos poligonales. Esporas elipsoidales, de 44-32 $\mu \mathrm{m}$, con perisporios sublisos, con algunos pliegues dispersos, finos e irregulares

Distribución geográfica y ecología. Estados Unidos, Europa y Asia. Crece en bosques, praderas, mallines, vegas, áreas graminosas y barrancos rocosos, turberas en sitios abiertos, generalmente en sustratos o suelos ácidos o arenosos; es marcadamente calcífuga y no suele crecer en suelos con arcillas. Desde el nivel del mar hasta los 1300 $\mathrm{m}$.

Observaciones. Esta especie se puede considerar el equivalente holártico de $B$. penna-marina y sus fenotipos son similares, especialmente si se comparan las plantas más robustas de $B$. penna-marina con las más pequeñas de $B$. spicant. Las citas de $B$. spicant para Asia parecen ser dudosas 
(Chambers \& Farrant, 1996 a). Ormonde (1986) menciona dos variedades: la variedad típica, con frondas dimorfas y la var. homophyllum, con frondas monomorfas o escasamente dimorfas. Los modelos epidérmicos de los segmentos y de los indusios de esa variedad son iguales a los de la variedad típica y se trataría de una planta pequeña, precozmente fértil o neoténica. En ambos casos, los modelos son similares a los de B. asperum, con sinuosidades compuestas. Para B. spicant, Manton et al. (1986) y Horjales et al. (1990) registran un número básico de $\mathrm{x}=34$.

Ejemplares de referencia: ESPAÑA: Galicia: Coruña, Fraga de Caaveiro, Prada $s / n$ (MACB). Orense, Valle de Valdeorras, El Mazo, Prada s/n (MACB). SUIZA: Flore $\mathrm{du}$ pays d'Enhaut: Les Mosses, bois clear, 1450 m, Pedersen 2486 (LP).

Blechnum stoloniferum (Mett. ex E. Fourn).

C. Chr., Index filic. 154. 1905.

Plantas terrestres, de selvas montanas y pedemontanas. Rizomas subterráneos a subepigeos y parcialmente erectos, formando un pequeño tronco de 4-6 cm, escamosos, con estolones abundantes, delgados y epigeos. Escamas rizomáticas lanceoladas, enteras, concolores, pardas, oscuras, de hasta 2-3 mm de largo, con margen subdenticulado a entero. Frondas dimórficas, las estériles de hasta $17-10 \mathrm{~cm}$ de largo, algo más cortas que las fértiles. Estípites surcados adaxialmente, de hasta $7 \mathrm{~cm}$ de largo en las frondas estériles y más largos, de hasta $16 \mathrm{~cm}$ en las fértiles, los estériles aproximadamente $1 / 5$ de la longitud total de la fronda y los fértiles más largos como las láminas, a veces atropurpúreos, purpúreos o de color magenta, con escamas, basales ovadas, más cortas que las rizomáticas, luego glabros, con epidermis papilosa, una zona hipodérmica fibrosa de 4-5 capas celulares de espesor, abundante parénquima no amiláceo y tres haces vasculares de tamaño similar. Lámina estéril lanceolada a lanceolado-elíptica, con ápice agudo y base cuneada, imparipinnada, pinnado-pinnatífida, raquis y costas glabras; segmentos 10-16 (20) pares, 0,3-1,5 cm de largo por $0,4-0,7 \mathrm{~cm}$ de ancho, los 3-7 pares basales aflébicos, de contorno semicircular; de textura herbácea y delicada a algo esponjosa, oblongos, con ápice redondeado y margen entero algo repando. Venas simples, visibles, terminadas en grandes hidatodos de contorno espatulado. Láminas fértiles elípticas, con 10-20 pares de pinnas muy contraídas. Indusio continuo, con margen recto y modelo epidérmico sinuoso frecuente. Esporas elipsoidales, de 40 × 28 $\mu \mathrm{m}$, con perisporio subliso, con micrornamentación granular dispersa.

Distribución geográfica y ecología. México, Mesoamérica. Selvas de neblina, desde los 200 hasta cerca de $3500 \mathrm{~m}$ de altitud, también en laderas volcánicas.

Observaciones. Moran (1995) la incluye en la sinonimia de B. l'herminieri, pero la aplicación de ese nombre se discute aún en relación con una posible sinonimia con $B$. lehmannii. El material de B. lehmannii estudiado aquí difiere claramente del de' $B$. stoloniferum por el contorno de las pinnas, la textura, la venación, la ausencia de indumento, el tipo de margen, a veces algo involuto y la morfología epidérmica. Rojas (2001) advierte que $B$. microlomaria, citada por Moran (1995) como un sinónimo de $B$. lherminieri, es realmente un sinónimo de $B$. stoloniferum y considera que es posible que material de esa especie procedente de Costa Rica y Panamá se esté determinando erróneamente como $B$. lherminieri.

Ejemplares de referencia: MÉXICO: Oaxaca: Mixes, NW slopes of Cerro Zempaltepetl, trail from Yacoche to Tototepec, Mickel \& Leonard 4661 (LP, NY). Teotitlán, 26-29 km NE of Teotitlán del 
Camino, vicinity of Pass at Puerto Soledad, Mickel \& Hellwig 4104 (LP, NY). Hidalgo, 5700 ft., Pringle 13808 (MO).

\section{CONCLUSIONES}

Los taxones aquí estudiados integran un grupo que tiene en común, entre otros caracteres, los esporófitos pequeños a medianos, con rizomas postrados a erectos y frondas marcadamente dimórficas, rasgos originalmente asignados por Tryon \& Tryon (1982) al grupo B. penna-marina. De acuerdo con nuestros resultados, el grupo puede caracterizarse, además, por los rizomas escamosos, los estípites papilosos, de sección cóncavo-convexa, con un solo surco adaxial y tres haces vasculares, las laminas pinnatífidas o pinnatisectas con segmentos adnatos al raquis, el indumento superficial representado por pelos uniseriados pluricelulares, los grandes hidatodos activos epifílicos, las esporas con perisporios lisos a rugulados y la reproducción vegetativa por medio de estolones. Las plantas son pequeñas a medianas, pero el tamaño sólo debería ser tomado en cuenta dentro de ciertos límites y considerando su relación con la altitud y la latitud, ya que parece variar en el rango de distribución de los taxones y no se relaciona claramente con otros caracteres: los ejemplares de B. mochaenum subsp. mochaenum y $B$. penna-marina con esporas, células epidérmicas y estomas más grandes son pequeños o están dentro del tamaño promedio de la especie.

Aunque los recuentos cromosómicos no son numerosos, los referentes al grupo parecen coincidir en un número básico de $\mathrm{x}=$ 33, si bien Manton \& Vida (1968) señalaron $\mathrm{x}=34$ para material de $B$. penna-marina de Nueva Zelanda y Manton et al. (1986) un mismo número para $B$. spicant. Los recuentos más recientes (Jara-Seguel'et. al., 2006), efectuados en material chileno de $B$. penna-marina y $B$. mochaenum subsp. mochaenum registran $2 \mathrm{n}=66$ y por ende, un número básico de $\mathrm{x}=33$, que aparece también en especies de otro grupos, como $B$. cordatum [como B. chilense (Kaulf.) Mett] y $B$. hastatum Kaulf.

El grado de contracción de las pinnas fértiles parece ser inconstante en el género y va desde una reducción moderada a completa de la superficie estéril, pero los taxones incluidos en el grupo B. pennamarina son marcadamente dimórficas y el megafilo esporógeno es un eje erguido cuyas pinnas laterales tienen una lámina extremadamente reducida.

En cuanto a la duración y el hábito, todos los taxones son perennes, coloniales y las comunidades se forman merced a la producción de estolones con una organización interna similar a la de los rizomas pero con una dictiostela con un número menor de meristelas. Los estolones son afilos y sólo los de B. asperum tienen aflebias semicirculares. La interpretación de esta condición como un caso de polimorfismo (de la Sota, 1970 b) o de frondas trimórficas (Oliveira Dittrich, 2005) no parece acertada, ya que tales estolones son cladodios aflébicos que reproducen vegetativamente las plantas y no frondas diferentes.

Blechnum andinum se excluyó de este estudio por falta de material para un análisis morfológico detallado. Es una especie saxícola, orófila, que crece en Perú, Bolivia y SE de Brasil, del que existen pocas colecciones. Oliveira Dittrich (2005) cita tres ejemplares de referencia, indicando que se habría coleccionado por última vez en Brasil hacia 1935 y estaría en peligro de extinción o eventualmente, ya extinguida. León (1999) la registra para Perú a partir de una colección efectuada por Bües en 1930 y señala que es 
escasa y crece en las laderas orientales de los Andes, sobre rocas y entre musgos, formando colonias que se reproducen vegetativamente. Fenotípicamente se asemeja mucho a $B$. corralense y a $B$. stoloniferum: es una planta pequeña y delicada, con frondas de unos $8-10 \mathrm{~cm}$, venas simples, presenta varios pares aflébicos basales y se reproduce por medio de estolones

Los caracteres estudiados tienen un valor diagnóstico variable. El tipo y contorno de las escamas rizomáticas y del estípite, el tipo de margen de las pinnas, el patrón y visibilidad de la venación, la presencia y tipos de pelos setiformes y de acúleos epidérmicos, el modelo epidérmico de las pinnas estériles, las dimensiones estomáticas, los modelos epidérmicos de los indusios y los perisporios son caracteres que varían en los niveles específico e infraspecífico.

Los estípites papilosos o pilosopapilosos, con escamas basales y 3 (2) haces vasculares podrían ser un rasgo de grupo. Las secciones transversales son muy similares en todos los taxones estudiados y la variación más importante se encuentra en el mayor o menor desarrollo de un surco adaxial, el tipo de epidermis, el grado de desarrollo de la capa hipodérmica de sostén, la presencia o ausencia de PIP y de almidón de reserva. Un análisis de mayor número de especies del género permitiría precisar el valor diagnóstico de este conjunto de caracteres.

La pubescencia de las láminas nunca es abundante (B. fernandezianum es una excepción) y el tipo de pelo, pluricelular uniseriado 3-4 (7) celular, capitado o no, es el más corriente en los taxones analizados y podría estar más difundido en el género, ya que es similar al que aparece en especies del grupo B. occidentale. Por el momento, la importancia del indumento de ejes y láminas como carácter diagnóstico en Blechnum requiere estudios adicionales que involucren especies de todos los grupos de afinidad.

La venación es un carácter útil y combinado con otros resulta diagnóstico en el nivel específico. Blechnum andinum, $B$. corralense y $B$. stoloniferum se destacan por las venas simples, mientras que los restantes taxones presentan venas simples combinadas con bifurcadas, con geminadas y bifurcadas o bien venas predominantemente bifurcadas, una o dos veces.

La epidermis es un rasgo que varía en el nivel específico e infraspecífico y en muchos casos es un indicador de la madurez del esporófito. Los estomas no tienen, por el momento, un valor diagnóstico claro: los tipos estomáticos parecen ser, con algunas variaciones específicas, un rasgo genérico y la densidad estomática podría estar reflejando aspectos ecológicos. En el grupo hay dos tipos estomáticos predominantes, diacíticos y anomocíticos y son ocasionales los tipos actinocíticos. Los hidatodos están presentes en todos los taxones del grupo, son grandes y sobresalientes, especialmente en el epifilo, pero igualmente, sería necesario analizar especies de otros grupos del género para precisar el valor diagnóstico de este carácter, ya que parece evidente que se los halla en un número relativamente amplio de taxones de algunos grupos y no en otros (Prada \& Rolleri, datos no publicados).

Los tipos de márgenes y los modelos epidérmicos de los indusios varían en el nivel específico e infraspecífico y son diagnósticos en los taxones de este grupo. El carácter puede ser útil en los casos en que las frondas esporógenas son inmaduras porque el indusio puede estar ya formado aún en ausencia de esporangios.

En cuanto a su morfología, las esporas podrían resultar un carácter diagnóstico importante, ya que los estudios esporales son aislados y no involucran correlaciones con grupos de especies. Los estudios esporales 
realizados son preliminares, pero puede adelantarse que el grupo se caracteriza por las esporas con exosporios lisos y perisporios poco ornamentados. Blechnum fernandezianum y B. mochaenum subsp. squamipes tienen esporas muy diferentes de B. mochaenum subsp. mochaenum y de otros taxones del grupo, mientras que las esporas de $B$. microphyllum y $B$. penna-marina son muy semejantes. Blechnum corralense y $B$. stoloniferum, dos especies con frondas pequeñas y segmentos herbáceos o membranáceos, con márgenes subenteros y venas simples tienen esporas con perisporios casi lisos con micrornamentación granular.

Los grupos informales propuestos por Tryon \& Tryon (1982) resultan útiles, en un género amplio como Blechnum, para enfocar el análisis de especies fenotípicamente similares, pero tal como están planteados son algo rígidos. A medida que se estudian nuevas colecciones surgen nuevas evidencias sobre los límites y las afinidades de las especies y es posible suponer que en un futuro, los grupos serán más naturales, más amplios y estarán definidos sobre la base de un mayor número de caracteres. Análisis preliminares no publicados sugieren que otras especies americanas, como B. fragile, B. kunthianum C. Chr. y B. wardiae Mickel \& Beitel, además de algunas de Africa y Oceanía, podrían formar parte del grupo $B$. penna-marina.

AGRADECIMIENTOS. Este trabajo fue realizado en el Laboratorio de Anatomía Vegetal Evolutiva y Sistemática (LEAVES), de la Facultad de Ciencias Naturales y Museo de La Plata y en el Departamento de Biología Vegetal I de la Facultad de Biología, de la Universidad Complutense de Madrid, España, con el apoyo de las siguientes Instituciones: Agencia Española de Cooperación Internacional para la realización de un proyecto conjunto de investigación (Referencia AECI 1943/04); la Universidad Complutense de Madrid, España; Consejo Nacional de Investigaciones Científicas y Técnicas de Buenos Aires (CONICET) y
Programa de Incentivos para Docentes Investigadores de la Universidad Nacional de La Plata (Argentina). Las autoras desean agradecer expresamente al Dr. Raúl Perdomo, Vicerrector de la Universidad de La Plata, al Dr. José Luis Hormaechea, Director de la Estación Astronómica Austral, de Río Grande, Tierra del Fuego, Argentina, por el apoyo brindado en el curso de los estudios de campo y a la Dra. Lilian Passarelli (LEAVES; FCNyM, La Plata), quien preparó las muestras de esporas y realizó las fotografías que ilustran este trabajo.

\section{BIBLIOGRAFÍA}

AMIGO, J., C. RAMÍREZ y A. RUDLOFF 1996- No doblarán las campanas por Blechnum corralense Espinosa. Datos y reflexiones sobre una especie endémica amenazada de extinción. Revista Chile Forestal 25, 282: 30-33.

BANNISTER, P. \& B. FAGAN -1989- The frost resistance of fronds of Blechnum pennamarina in relation to season, altitude, and short term hardening and dehardening. New Zealand Journal of Botany 27: 471-476.

BERCU, R. -2000- Structural variations concerning organization of vascular system in some ferns correlated to their habitat. http:/ /www.tnu.crimea.ua/tnu/magazine/pontida/ 2000/bercu.htm

BURROWS, J. E. -1999- Southern African ferns and fern-allies. Frandsen Publishers (Pty) Ltd., Sandton.

CHAMBERS, T.C. -1954- Experimental studies on the genus Blechnum in New Zealand. Tesis; ined. Aukland University College, University of New Zealand.

CHAMBERS, T.C. \& FARRANT, P.A. -1996aFour subspecies of the fern Blechnum pennamarina ( Blechnaceae-Pteridophyta). Fern Gazette 15: 91-100.

CHAMBERS, T.C. \& FARRANT, P.A. -1996bBlechnum blechnoides (Bory) Keyserling (Blechnaceae), formerly B. banksii (Hook. f.) Mett. ex Diels, a fern from salt-spray habitats of New Zealand and Chile. New Zealand Journal of Botany 34: 441-445.

CODEFF, -2002- Plan de Manejo de Area Silvestre Privada Protegida Punta 
Curiñanco, Comité Nacional pro defensa de la Fauna y la Flora (CODEFF). Valdivia, 99 pag.

COPELAND, E. B. -1947-Genera Filicum. Waltham, Mass.

DUNCAN, B. \& ISAAC, G. -1986- Ferns and allied plants of Victoria, Tasmania and South Australia. Melbourne University Press.

DURÁN, M. L. -1997-Estudios morfólogicos, taxonómicos y biosistemáticos en el género Blechnum. Blechnaceae-Pteridophyta. Tesis Doctoral, inéd. Facultad de Ciencias Exactas, Físicas y Naturales. Universidad Nacional de Córdoba. Argentina.

FERNÁNDEZ, N., S FONTENLA y M. I. MESSUTTI -2005-Micorrizas en pteridófitos de los bosques templado-lluviosos del noroeste de Patagonia. II Convención Ambiental Universitaria Patagónica, Biología. UNComahue, Bariloche, Argentina.

GARDINER, W. -1985- The continuity of the protoplasm in plant tissue. Nature 17: 390391.

HABERLANDT, G. -1965- Physiological plant anatomy. Today \& Tomorrow Book Agency, New Delhi-5.

HOLMGREN, P. K., N. H. HOLMGREN \& L. BARNETT -1990- Index Herbariorum, Part I: Herbaria of the World. New York Botanical Garden, Bronx, New York.

HORJALES, M., N. M. REDONDO y J. M. PÉEZ PREGO -1990- Nota citotaxonómica sobre pteridoflora del noroeste de la península Ibérica. Anales del Jardín Botánico de Madrid 48: $82-84$.

JARA-SEGUEL, P., M. ROMERO-MIERES y C. PALMA-ROJAS -2006- Números cromosómicos de Pteridófitos chilenos: primera contribución. Gayana, Botánica 63(1): 115-118.

KASMIRCZAK, C. -1999- A familia Blechnaceae (C. Presl) Copel. (Pteridophyta) no Rio Grande do Sul. Tesis (Grau do Mestre), Universidade Federal do Rio Grande do Sul.

LELLINGER, D. B. -1985- A Field Manual of the Ferns and Fern Allies of the United States and Canada. Smithsonian Unicersity Press, Washington, D. C.

LELLINGER, D. B. -2002- A Modern Multilingual Glossary of taxonomic
Pteridology. Pteridologia 3, 246 pp.

LELLINGER, D. B. -2003- Nomenclatural and taxonomic notes on the Pteridophytes of Costa Rica, Panamá and Colombia, III. Amer. Fern J. 93 (3): 146-151.

LELLINGER, D. B. \& W. C. TAYLOR -1997- A classification of spore ornamentation in the Pteridophyta. pp. 33-42, en R. J. Johns (ed.), Holttum Memorial Volume. Royal Botanic Gardens, Kew.

LEÓN, B. -1999- Blechnum penna-marina in Perú. American Fern Journal 89 (4): 267-269.

LOOSER, G. -1947- Los Blechnum (Filices) de Chile. Revista de la Universidad Católica de Chile 32(2): 7-104.

LUERSSEN, C. -1975- Untersuchungen über die Interzellularverdickungen in Grundgewebe der Farne. Botanische Zeitung (Berlin) 33:704-705, 718-728.

LUGARDON, B. -1965- Structure des parois de la spore de Blechnum spicant (L.) Roth. Pollen et spores 7 (3): 409-428.

LUGARDON, B. -1974- La structure fine de 1'exospore et de la périspore des Filicinées isosporées, II. Filicales. Commentaires. Pollen et Spores 16 (2): 161-226.

MANGIN, M.L. -1893- Recherche sur les composés pectiques. Journal de Botânique, Paris 7:37-47, 121-131, 325-343.

MANTON, I., J. \& J. D. VIDA - 1968- Cytology of the fern flora of Tristan da Cunha. Proceedings of the Royal Society of London, Botany 170: 361-379.

MANTON, I., J. LOVIS, G. VIDA \& M. GIBBY -1986- Cytology of the fern flora of Madeira. Bulletin of the British Museum (Natural History), Botany 15(2): 123-161.

MARTICORENA, C. y M. QUEZADA -1985Catálogo de la Flora Vascular de Chile. Gayana, Botánica 42: 1- 57.

MICKEL, J. T. \& J. M. BEITEL -1988Pteridophyte flora of Oaxaca, Mexico. Memoirs of the New York Botanical Garden 46. $568 \mathrm{p}$.

MICKEL, J. T. \& SMITH, A. R. -2004- The Pteridophytes of Mexico. Memoirs of the New York Botanical Garden. 88: 1-1054

MORAN, R.C. -1995- Blechnaceae, 325-333, en: Davidse, G., Souza, M. \& Knapp, S. (eds.), $F l$. Mesoamericana I, Psilotaceae a 
Salviniaceae. Universidad Autónoma de México, Missouri Botanical Garden \& The Natural History Museum (London).

MORBELLI, M. A. -1976- Estudio palinológico de las especies austrosudamericanas del género Blechnum L., subgénero Blechnum (Blechnaceae-Pteridophyta). Boletín Sociedad Argentina de Botánica 17 (1-24): 5-24.

OGURA, Y. -1972- Comparative Anatomy of the Vegetative Organs of the Pteridophyta, en: W.Zimmerman, S. Carlquist, P. Ozenda \& H. D. Wulff (Eds.), Encyclopedia of Plant Anatomy vol. 7. Berlín.

OLIVEIRA DITTRICH, V. A. -2005-Estudos taxonômicos no gênero Blechnum L. (Pteridophyta-Blechnaceae) para as regiões Sudeste e Sul do Brasil. Tesis Doctoral, Universidad Estadual Paulista Julio de Mesquita Filho, Rio Claro, São Paulo, Brasil, $223 \mathrm{pp}$.

ORMONDE, J. -1986- Blechnum, in: Castroviejo et al. (eds.), Flora Ibérica, I, LycopodiaceaePapaveraceae: 151-153. Real Jardín Botánico, C.S.I.C., Madrid

POTGIETER, M. J \& A.E. VAN WYK -1992Intercellular pectic protuberances in vascular plants: their structure and taxonomic significance. Botanical Bulletin of Academia Sinica 33: 295-3-16.

PRABHAKAR, M. -2003- Structure, delimitation, nomenclature and classification of stomata. Acta Botanica Sinica. 46 (2): 242252. 2003.

PRADA, C. \& C. H. ROLLERI -2005- A new species of Isoetes L. (Isoetaceae) with a study of microphyll intercellular pectic protuberances and their potential taxonomic value. Botanical Journal of the Linnean Society 147 (2): 213-228.

RODRÍGUEZ-RÍOS, R. -1973- Morfología de los protalos y esporofitos jóvenes de algunas especies chilenas de Blechnum (Polypodiaceae s.1.). Gayana, Bot. 22: 1-30.

RODRÍGUEZ-RÍOS, R. -1995- Pteridophyta en: Marticorena, C. et al. (ed.), Flora de Chile, 1. Pteridophyta - Gymnospermae, XVI. Chile, 351 pag.

ROJAS, A. F. -2001- Seis especies nuevas y dos nuevos registros de helechos (Pteridophyta) para Costa Rica. Revista de Biología Tropical 49: 435-452.

ROLLERI, C. H. -1976- Estudios morfológicos y sistemáticos en especies e híbridos interespecíficos de Blechnum L.., Blechnaceae - Pteridophyta. Boletín de la Sociedad Argentina de Botánica 17(1 -2): 5 25.

ROLLERI, C. H. -1984- Ontogenia y semofilesis de las lenticelas de algunas Filicophyta, con especial referencia a las presentes en Blechnum chilense (Kaulf.) Mett., Blechnaceae. Revista del Museo de La Plata, n. s., Botánica 13 (74): 165 - 187.

ROLLERI, C. -2004- Revisión del género Danaea (Marattiaceae-Pteridophyta). Darwiniana 42 (1-4): 217-301.

ROLLERI, C. H., A. M. DEFERRARI \& M. C. CICIARELLI -1987- Epidermis y estomatogénesis en Marattiaceae. Revista del Museo de La Plata, n. s., Botánica 14 (91): $129-147$.

ROlleri, C. H., M. C. LAVAlle, A. MENGASCINI y M. RODRÍGUEZ -1999Protuberancias intercelulares pécticas en especies de Angiopteris Hoffm. y otras Marattiales. Physis (Buenos Aires), C, 57 (132-133): 1-11.

ROLLERI, C. y C. PRADA -2006- Catálogo comentado de las especies mesoamericanas y sudamericanas de Blechnum L., Blechnaceae-Pteridophyta. Anales del jardín Botánico de Madrid 63 (1): 67-106.

SCHELPE, E. A. C. L. E. -1952- A revision of the African species of Blechnum. Journal of the Linnean Society of London (Botany) L. III (355): 487- 510.

SCOGGAN, H. J. -1978- Pteridophyta, Gymnospermae, Monocotyledoneae. The Flora of Canada 2: 93-545.

SMITH, A.R. \& MICKEL, J.T. -1977Chromosome counts for Mexican ferns. Brittonia 29: 291-294

SOTA, de la, E. R. -1970a- Notas sobre las especies austrosudamericanas del género Blechnum L., I, Blechnum penna-marina. Boletín Sociedad Argentina de Botánica 13 (2-3) : 129- 139.

SOTA, de la, E. R. -1970b- Notas sobre las especies austrosudamericanas del género 
Blechnum L., II, Polimorfismo en Blechnum. Boletín Sociedad Argentina de Botánica 13 (2-3) : 140- 144.

SOTA, de 1a, E. R. - $1972^{\mathrm{a}}$ - Notas sobre las especies austrosudamericanas del género Blechnum L., III, El género Blechnum en la provincia de Buenos Aires. Boletín Sociedad Argentina de Botánica. 14 : 177-197.

SOTA, de la, E. R. -1972b- Notas sobre las especies austrosudamericanas del género Blechnum L., VI, Blechnum blechnoides Kayserl. y Blechnum mochaenum Kunkel. Boletín Sociedad Argentina de Botánica 14(3): 190-197.

SOTA, de la, E. R. -1973-Sinopsis de las familias y géneros de Pteridohyta de Argentina, Uruguay y Chile.Revista Museo La Plata, n.s., Botánica 10:187-221.

SOTA, de la, E. R. - 1977- Familia Blechnaceae, En : Flora de la provincia de Jujuy, Argentina II, Pteridophyta. Colección Científica del INTA, Buenos Aires.

SPERRY, J. S. -1983- Observations on the structure and function of hydathodes in Blechnum lehmanii. American Fern Journal 73(3): 65-72.

STOLZE, R.G. -1981- Ferns and fern allies of Guatemala. Part 2: Polypodiaceae. Fieldiana, Botany, new series 6: 1-522.

TAYLOR, T. M. C. -1970- Pacific Northwest Ferns and Their Allies. 247 pp.

THURSTON, E. L. -1969- Taxonomic significance of of stomatal patterns in the ferns. American Fern Journal 59: 68-79.

TRYON, A. F. \& B. LUGARDON -1990- Spores of the Pteridophytes: Surface, wall structure, and diversity based on electron microscope studies. Springer-Verlag, Nueva York.

TRYON, R.M. \& R.G. STOLZE -1993Pteridophyta of Peru. Part. 5: AspleniaceaePolypodiaceae. Fieldiana, Botany, new series 32: $54-70$.
TRYON, R. M. \& A. F. TRYON -1982- Ferns and fern-allies from Tropical America. Springer-Verlag, Nueva York.

VAN COTTHEM, W. R. J. -1970- Comparative morphological study of the stomata in Filicopsida. Bull. Jard. Bot. Belg. 40: 81-239.

VAN COTTHEM, W. R. J. -1973- Stomatal types and Systematics: 59-7, in Jermy A. C., Crabbe, J. A. \& Thomas, B. A. (eds.), The phylogeny and classification of ferns, Botanical Journal of the Linnean Society 67, suppl. 1. Academic Press, London.

Aceptado para su publicación en octubre de 2006

Dirección de los autores. C. H. ROLLERI: Laboratorio de Estudios de Anatomía Vegetal Evolutiva y Sistemática (LEAVES), Facultad de Ciencias Naturales y Museo de La Plata, 64 entre 120 y diagonal 113, B1904 DZB, La Plata, Argentina.tinar@speedy.com.ar; C. PRADA: Departamento de Biología Vegetal I, Facultad de Ciencias Biológicas, Universidad Complutense, Ciudad Universitaria, 28040 Madrid, España. cpm@bio.ucm.es 